\title{
First estimation of the diffusive methane flux and concentrations from Lake Winnipeg, a large, shallow and eutrophic lake
}

\author{
Rachel R. Mandryk ${ }^{\mathrm{a},}{ }^{,}$, David W. Capelle ${ }^{\mathrm{a}, 1}$, Cara C. M. Manning ${ }^{\mathrm{b}, 2}$, Philippe Tortell ${ }^{\mathrm{b}, \mathrm{c}}$, Ross \\ D. McCulloch ${ }^{\mathrm{b}}$, and Tim Papakyriakou ${ }^{\mathrm{a}}$ \\ ${ }^{a}$ Centre for Earth Observation Science, University of Manitoba, Winnipeg, MB, Canada \\ ${ }^{b}$ Department of Earth, Ocean and Atmospheric Sciences, University of British Columbia, \\ Vancouver, BC, Canada \\ ' Department of Botany, University of British Columbia, Vancouver, BC, Canada \\ ${ }^{*}$ Corresponding Author: rachelmandryk@gmail.com \\ ${ }^{1}$ Current address: Freshwater Institute, Fisheries and Oceans Canada, Winnipeg, MB, \\ Canada \\ ${ }^{2}$ Current address: Plymouth Marine Laboratory, Plymouth, UK
}

This document is the author's accepted manuscript of an article published in Journal of Great Lakes Research (https://doi.org/10.1016/j.jglr.2021.03.011) and is shared under a CC-BY-NC-ND license. Please cite the published article.

\section{Citation:}

Rachel R. Mandryk, David W. Capelle, Cara C.M. Manning, Philippe Tortell, Ross D. McCulloch, Tim Papakyriakou, First estimation of the diffusive methane flux and concentrations from Lake Winnipeg, a large, shallow and eutrophic lake, 2021, Journal of Great Lakes Research, 47(3), 741-750, https://doi.org/10.1016/j.jglr.2021.03.011. 


\begin{abstract}
Freshwater lakes are increasingly recognized as significant sources of atmospheric methane $\left(\mathrm{CH}_{4}\right)$, potentially offsetting the terrestrial carbon sink. We present the first study of dissolved $\mathrm{CH}_{4}$ distributions and lake-air flux from Lake Winnipeg, based on two-years of observations collected during all seasons. Methane concentrations across two years had a median of value of $24.6 \mathrm{nmol} \mathrm{L}^{-1}$ (mean: $41.6 \pm 68.2 \mathrm{nmol} \mathrm{L}^{-1}$ ) and ranged between 5.0 and $733.8 \mathrm{nmol} \mathrm{L}^{-1}$, with a 2018 annual median of $24.4 \mathrm{nmol} \mathrm{L}^{-1}$ (mean: $46.8 \pm 99.3 \mathrm{nmol} \mathrm{L}^{-1}$ ) and $25.1 \mathrm{nmol} \mathrm{L}^{-1}$ (mean: $38.8 \pm 45.2 \mathrm{nmol} \mathrm{L}^{-1}$ ) in 2019. The median lake-air flux was $1.1 \mu \mathrm{mol} \mathrm{m}^{-2} \mathrm{~h}^{-}$ ${ }^{1}$ (range: $0.46-70.1 \mu \mathrm{mol} \mathrm{m}{ }^{-2} \mathrm{~h}^{-1}$, mean: $2.9 \pm 10.2 \mu \mathrm{mol} \mathrm{m}{ }^{-2} \mathrm{~h}^{-1}$ ) in 2018 , and $5.5 \mu \mathrm{mol} \mathrm{m}^{-2} \mathrm{~h}^{-1}$ (range: $0.0-78.4 \mu \mathrm{mol} \mathrm{m}{ }^{-2} \mathrm{~h}^{-1}$, mean: $2.7 \pm 8.5 \mu \mathrm{mol} \mathrm{m}^{-2} \mathrm{~h}^{-1}$ ) in 2019 , for a total diffusive emission of $0.001 \mathrm{Tg}$ of $\mathrm{CH}_{4}-\mathrm{C} \mathrm{yr}^{-1}$. We found evidence of consistent spatial variability, with higher concentrations near river inflows. Significant seasonal trends in $\mathrm{CH}_{4}$ concentrations were not observed, though fluxes were highest during the fall season due to strong winds. Our findings suggest Lake Winnipeg is a $\mathrm{CH}_{4}$ source of similar mean magnitude to Lake Erie, with lower concentrations and fluxes per unit area than smaller mid- to high-latitude lakes. Additional work is needed to understand the factors underlying observed spatial variability in dissolved gas concentration, including estimations of production and consumption rates in the water column and sediments.
\end{abstract}

Keywords: Methane, Carbon Cycling, Lake Winnipeg, Greenhouse Gases 


\section{Introduction}

Methane $\left(\mathrm{CH}_{4}\right)$ is a potent climate-active gas that accounts for 20 percent of total greenhouse warming (IPCC, 2013), and whose atmospheric concentration has increased 2.5fold since the pre-industrial period (Wolff and Spahni, 2007). While the largest atmospheric sources of $\mathrm{CH}_{4}$ are anthropogenic, natural production of this gas is an important carbon loss pathway from terrestrial and aquatic systems, offsetting an estimated 25 percent of the terrestrial carbon sink with lakes and rivers, and accounting for approximately 12 percent of the non-anthropogenic $\mathrm{CH}_{4}$ flux to the atmosphere (Bastviken et al., 2011, 2004; Huutenen et al., 2003; Kirschke et al., 2013). Ongoing eutrophication is expected to increase the $\mathrm{CH}_{4}$ flux from lakes over the coming decades, potentially making lakes the largest natural source of $\mathrm{CH}_{4}$ to the atmosphere (Bastviken et al., 2011; Beaulieu et al., 2019).

The majority of $\mathrm{CH}_{4}$ in lakes is produced in anoxic sediments by methanogenic archaea during anaerobic metabolism (Bastviken et al., 2004; Borrel et al., 2011). Water column production can occur under anoxic conditions, and oxic $\mathrm{CH}_{4}$ production has also been recently documented (Bastviken et al., 2004; Borrel et al., 2011; Bogard et al., 2014; Peeters et al., 2019). Much of the $\mathrm{CH}_{4}$ produced in anoxic environments is oxidized to $\mathrm{CO}_{2}$ by methanotrophic bacteria in oxygenated waters, but surface water $\mathrm{CH}_{4}$ super-saturation is still a common feature in lakes, driving net $\mathrm{CH}_{4}$ evasion to the atmosphere (Bastviken et al., 2004). Previous research has shown that lake $\mathrm{CH}_{4}$ concentrations and emissions vary with latitude, and are influenced by the physical and biological characteristics of the waterbody, including temperature, nutrient status, algal communities, predominant form of organic matter, and mixing patterns (Bastviken et al., 2004; Emilson et al., 2018; Fernandez et al., 2020; Rasilo et al., 2015). Indeed, lake $\mathrm{CH}_{4}$ fluxes have shown close relationships with total phosphorus, biological production, and sediment temperature (DelSontro et al., 2016). Accordingly, temperate, subarctic and boreal lakes tend to have relatively lower $\mathrm{CH}_{4}$ flux per unit area than tropical lakes, but their larger combined surface area makes them a significant $\mathrm{CH}_{4}$ source to the atmosphere (Bastviken et al., 2011, 2004; Gonzalez-Valencia et al., 2014; Kirschke et al., 2013).

Roughly nine percent of Canada is covered by lakes, and this country contains eight of the twenty largest lakes in the world (Statistics Canada, 2018). To date, there have been 
relatively few studies of $\mathrm{CH}_{4}$ emissions from North American great lakes, with recent exceptions from Lake Erie, Michigan, and Superior (Beeton, 1963; Fernandez et al., 2020; Joung et al., 2019; Lu et al., 2010). Here, we present dissolved $\mathrm{CH}_{4}$ measurements and estimates of $\mathrm{CH}_{4}$ flux from Lake Winnipeg, a large, shallow mid-latitude lake in Manitoba. The lake, which is the $11^{\text {th }}$ largest by surface area in the world, has been relatively well-studied in terms of its physical characteristics, nutrient status, and fisheries (Environment and Climate Change Canada [ECCC] and Manitoba Agriculture and Resource Development [MARD], 2020), yet no published measurements of $\mathrm{CH}_{4}$ concentrations or flux estimates exist. The objectives of this research are to estimate air-water flux during open water season in Lake Winnipeg, characterize the spatial and temporal (seasonal) variability in dissolved methane distributions, and to identify key drivers of spatiotemporal $\mathrm{CH}_{4}$ variability.

\section{Methods}

Study Area - Lake Winnipeg

Lake Winnipeg has a total surface area of $23,750 \mathrm{~km}^{2}$ (ECCC and ARD, 2020), with a watershed that occupies nearly one million square kilometers. The western half of the watershed is dominated by agriculture and prairie landscape largely overlying carbonate rocks, while the eastern side is dominated by boreal forest, shield lakes, and some hydroelectric development (Levesque and Page, 2011). The basin consists of granitic bedrock to the east and carbonate bedrock to the west, overlain in some places by glacial till and/or fine-grained clay to sandy sediments of varying thicknesses up to $100 \mathrm{~m}$ (Levesque and Page, 2011; Todd et al., 1997). The lake is typically ice-covered from late November to May (McCullough, 2020).

The lake consists of a north and south basin, separated by a constricted section referred to as the narrows (Fig.1; Levesque and Page, 2011). The two basins are significantly different from each other in terms of their water chemistry and physical characteristics (Watchorn, 2020). The average depth is $8 \mathrm{~m}$ in the south basin and $14 \mathrm{~m}$ in the north basin, with the deepest point at just over $60 \mathrm{~m}$ located in the narrows (Levesque and Page, 2011). The north basin is cooler than the south basin (Levesque, 2011; McCullough and Levesque, 2011), though both water and air temperatures have increased over the last several decades (Smith, 2020). Total suspended solids (TSS) are generally higher in the south basin than the north basin, which 
promotes higher primary productivity in the north basin (McCullough and Levesque, 2011). The lake has a large fetch, approximately $400 \mathrm{~km}$ north to south, $111 \mathrm{~km}$ west to east in the north basin, and $40 \mathrm{~km}$ west to east in the south basin, which allows for seiches to occur (Levesque and Page, 2011). Due to its large fetch and shallow depth Lake Winnipeg is completely polymictic in the south and north basins, stratifying rarely, though increasingly often in the north basin during the open water season, and occasionally beneath the ice in the winter (McCullough and Levesque, 2011; McCullough, 2020). The water column remains oxygenated year-round, with the lowest recorded dissolved oxygen concentration of below $2.5 \mathrm{mg} \mathrm{L}^{-1}$ at the bottom of the lake in the north basin in summer of 2003 (McCullough and Levesque, 2011). Less than 3\% of observations from 2008 - 2016 had dissolved oxygen concentrations of less than $5 \mathrm{mg} \mathrm{L}^{-1}$ (McCullough, 2020), suggesting methanogenesis is largely restricted to sediments. Lake Winnipeg has been characterized as a hypereutrophic lake that frequently experiences large scale algal blooms, and these are typically most severe along the eastern half of the lake's north basin (Binding 2020). Primary inflows to the lake are the Winnipeg River (43 percent of inflow) and Red River (12 percent of inflow). However, the Red River is by far the largest single nutrient source to the lake, supplying 69 percent of the total phosphorus and 34 percent of the total nitrogen to the lake (Delavau and Lee, 2020; ECCC and ARD, 2020; Wiebe, 2020). The lake drains to the northeast into the Nelson River, which flows to Hudson Bay. The lake level has been regulated through structures along the Nelson River for hydroelectric purposes since the 1970s (Watchorn, 2020), which has reduced the frequency of extreme lake levels by increasing outflow during high water years, and reducing outflow during low water years (Levesque and Page, 2011). The shoreline is predominantly rocky with some sandy beaches. Extensive marshland can be found near the mouths of some rivers, the largest being the Netley-Libau marsh at the south end of the lake near the mouths of the Red River and Netley Creek (Watchorn et al., 2012). Large amounts of commercial agricultural development are in Lake Winnipeg's southern and western portions of its watershed, across three provinces and four American states (Watchorn, 2020; Wiebe, 2020). The eastern and northern regions drain from predominantly forested areas (Watchorn, 2020). 


\section{Sampling}

Sampling was conducted from the MV Namao during the summer (July 31 - August 16 2018; July 23 - August 8, 2019), fall (September 24 - October 22, 2018; September 16 October 3, 2019), and spring (May 29 - June 13, 2019) cruises, and by helicopter during February 2019. The lake had a complete ice cover by December 2018. Near shore stations (designated by NS in Fig. 2) were sampled by a small boat deployed from the Namao in $1-3 \mathrm{~m}$ deep water (typically $10-100 \mathrm{~m}$ from shore). A total of 43 and 37 samples were taken in summer 2018 and fall 2018, respectively. In 2019, 35 stations were selected to be sampled. All stations were sampled at one-meter depth and an additional sample was collected one meter above the bottom at "W" stations (Fig. 2).

Water samples were collected using a rosette (SBE 55 ECO Water Sampler) equipped with six 2 L Niskin bottles, an SBE-43 Oxygen sensor, a Turner CYCLOPS-7 Turbidity sensor, a SEACATplus conductivity, temperature, depth sensor, and a Biospherical QSP-2300L photosynthetically active radiation (PAR) sensor providing information on dissolved oxygen, turbidity, transmitted PAR with depth at discrete stations of the cruise. Water samples for $\mathrm{CH}_{4}$ analysis were collected from the rosette Niskins into $60 \mathrm{~mL}$ glass vials using gas-tight tubing and ensuring no air bubbles entered the water sample. The bottle was filled with no headspace after overfilling with three times the vial volume.

Winter samples were collected using a Kemmerer bottle, which was deployed through a hole cut in the ice and sampled in the same manner as described using the Niskin bottles, but instead into a $500 \mathrm{~mL}$ glass biological oxygen demand (BOD) bottle. These were flushed with three times the sample volume before capping with a sintered glass stopper. Nearshore station samples were collected by submerging a $500 \mathrm{~mL}$ BOD bottle with a piece of tubing to act as a snorkel, which allowed removal of air from the submerged bottle via the tubing without creating bubbles inside the bottle, and capped. Water for $\mathrm{CH}_{4}$ analysis was then subsampled from the $500 \mathrm{~mL}$ glass BOD bottle, which was sealed and stored in the dark until processing, approximately thirty minutes after collection from nearshore sites, and 12-16 hours after sampling in the winter. A $60 \mathrm{~mL}$ glass syringe with tubing on the end was rinsed with sample water three times and used to transfer water from the BOD bottle to $60 \mathrm{~mL}$ serum bottles 
without introducing bubbles. The bottles were overfilled by $50 \%$ at minimum. Prior to sealing the vials with a butyl rubber stopper and aluminum crimp seal, $40 \mu \mathrm{L}$ of saturated mercuric chloride $\left(\mathrm{HgCl}_{2}\right)$ solution was added for preservation. The samples were stored in the dark at room temperature and were analysed by a purge-and-trap gas-chromatograph mass-

spectrometer at the University of British Columbia, following methods outlined by Capelle et al (2015). This method provides precision of $<3 \%$ and a detection limit of $<0.5 \mathrm{nmol} \mathrm{CH}_{4} \mathrm{~L}^{-1}$.

Instantaneous lake-air $\mathrm{CH}_{4}$ flux estimation

Lake-air $\mathrm{CH}_{4}$ flux $\left(\mathrm{F}, \mu \mathrm{mol} \mathrm{m} \mathrm{m}^{-2} \mathrm{~h}^{-1}\right)$ was estimated using the bulk flux equation (e.g., Wanninkhof, 2014):

$$
F\left(\mathrm{CH}_{4}\right)=k_{\mathrm{CH} 4}\left(\mathrm{C}_{w}-\mathrm{C}_{a}\right) \text {, }
$$

where $\mathrm{k}_{\mathrm{CH} 4}$ is the gas transfer velocity $\left(\mathrm{m} \mathrm{h}^{-1}\right)$ for $\mathrm{CH}_{4}, \mathrm{C}_{w}$ is the dissolved $\mathrm{CH}_{4}$ of the sample and $\mathrm{C}_{a}$ is the equilibrium $\mathrm{CH}_{4}$ concentration $\left(\mathrm{nmol} \mathrm{L}^{-1}\right.$ ) that would be expected at the water surface boundary layer in contact with the atmosphere given the temperature and salinity of the water, and the atmospheric $\mathrm{CH}_{4}$ concentrations. Atmospheric $\mathrm{CH}_{4}$ concentrations were obtained from the nearest NOAA monthly sampling station in Park Falls, Wisconsin, ranging from 1894.4 to 2006.0 ppb (Dlugonecky et al. 2020). Equilibrium $\mathrm{CH}_{4}$ concentrations were calculated following Wiesenburg and Guinasso (1979). The difference between measured $C_{w}$ and calculated $C_{a}$ (i.e., $\left.\Delta \mathrm{C}_{\mathrm{CH} 4}\right)$ is the excess concentration and was converted from $\mathrm{nmol} \mathrm{L}^{-1}$ to $\mu \mathrm{mol} \mathrm{m}^{-3}$ for input to Equation 1. The transfer velocity is often derived as a function of wind speed, and here we opted for the updated relationship for $\mathrm{CO}_{2}$ reported by Wanninkhof et al., (2014):

$$
k_{\mathrm{CO} 2_{2} 600}=\left[0.251 \cdot U^{2} \cdot\left(S c_{\mathrm{CO} 2} / 600\right)^{-0.5}\right] /_{100}
$$

and scaled to $\mathrm{CH}_{4}$ using:

$$
\frac{k_{\mathrm{CO}_{2} 600}}{k_{\mathrm{CH}{ }_{-} 600}}=\left(\frac{S c_{\mathrm{CO}_{2}}}{S c_{\mathrm{CH} 4}}\right)^{-0.5}
$$

where $\mathrm{SC}_{\mathrm{CO}}$ and $\mathrm{Sc}_{\mathrm{CH}} 4$ are the Schmidt Numbers for $\mathrm{CO}_{2}$ and $\mathrm{CH}_{4}$ (Jähne et al.,1987; Wanninkhof et al., 2014) for freshwater ( $\mathrm{Sc}=600)$, and $U$ is the wind speed at $10 \mathrm{~m}$ elevation. 


\section{Annual Flux Estimation}

To obtain an annual open water flux estimate, we used the 2019 dataset only, as no data was available for the spring season of 2018. We derived median daily flux values for each season where spring, summer, and fall were defined as May 1 - June 30; July 1 - August 31; and September 1 - November 30, respectively. We then multiplied median daily fluxes by the number of days during the corresponding season (i.e. spring = 61 days from May 1 - June 30), and then summed the three open-water seasons to obtain an annual flux. In doing so we assumed zero $\mathrm{CH}_{4}$ flux in winter. The porosity of freshwater ice is very low at near freezing temperatures (Craig and Hayward, 1987; Gosink, 1976) and consequently gas diffusivity rates in freshwater ice are negligible (Hemminsen, 1959). Our assumption is that fluxes during the partial ice cover periods (roughly May and November) would not be reduced by the presence of ice, though this may be an oversimplification (e.g., Manning et al., 2019) which may lead to an overestimation in annual $\mathrm{CH}_{4}$ loss to the atmosphere. Although we feel this assumption will have a small impact on annual total $\mathrm{CH}_{4}$ loss, we intend to investigate it further in subsequent studies. We note that our annual lake fluxes derived using median values were $\sim 50 \%$ lower than those calculated using means.

\section{Results}

Because of logistical constraints, not all stations shown in Figure 2 were sampled during each cruise. Despite these limitations, the distribution of samples in spring and summer provide a balanced representation of the lake north to south and east to west (Fig. 2). Sampling in winter was most constrained given the requirement for helicopter support. Consequently, we are missing winter samples in the northwest of the north basin and in proximity to the east shore of the south basin.

Average wind speed was greatest during the fall cruises (Table 1). In fall 2018, the average wind speed was $5.4 \pm 1.6 \mathrm{~m} \mathrm{~s}^{-1}$ (range: $2.1-7.7 \mathrm{~m} \mathrm{~s}^{-1}$ ) in the north basin, $6.8 \pm 3.6 \mathrm{~m} \mathrm{~s}^{-1}$ (range: $3.1-11.3 \mathrm{~m} \mathrm{~s}^{-1}$ ) in the south basin, and $5.7 \pm 2.3 \mathrm{~m} \mathrm{~s}^{-1}$ (range: $2.1-11.3 \mathrm{~m} \mathrm{~s}^{-1}$ ) across the entire lake. In fall 2019, the north and south basins showed higher wind speed variability and averaged $6.0 \pm 4.1 \mathrm{~m} \mathrm{~s}^{-1}$ (range: $0.5-14.9 \mathrm{~m} \mathrm{~s}^{-1}$ ) and $5.1 \pm 2.4 \mathrm{~m} \mathrm{~s}^{-1}$ (range: $1.3-12.9 \mathrm{~m} \mathrm{~s}^{-1}$ ) 
respectively in the north and south basins, with an average of $5.8 \pm 3.7 \mathrm{~m} \mathrm{~s}^{-1}$ (range: $0.5-14.9$ $\mathrm{m} \mathrm{s}^{-1}$ ) over the lake (Table 1). The lowest wind speeds were in spring 2019 (3.4 $\pm 2.1 \mathrm{~m} \mathrm{~s}^{-1}$, range: $\left.0.6-8.5 \mathrm{~m} \mathrm{~s}^{-1}\right)$ and summer $2019\left(2.8 \pm 1.5 \mathrm{~m} \mathrm{~s}^{-1}\right.$, range: $\left.0.3-5.8 \mathrm{~m} \mathrm{~s}^{-1}\right)$. Average water surface temperatures across the lake were highest in the summer cruises, being $19.7 \pm 1.3^{\circ} \mathrm{C}$ (range: $17.2-21.9^{\circ} \mathrm{C}$ ) in 2018 and $20.7 \pm 1.6^{\circ} \mathrm{C}$ (range: $17.2-23.3^{\circ} \mathrm{C}$ ) in 2019 , and lowest in fall of $2018\left(8.1 \pm 2.6^{\circ} \mathrm{C}\right.$, range: $\left.3.2-12.2^{\circ} \mathrm{C}\right)$ and in the north basin during spring $2019\left(8.3 \pm 2.7^{\circ} \mathrm{C}\right.$, range: $4.9-13.1^{\circ} \mathrm{C}$ ). The south basin on average was warmer than the north basin across all seasons (Table 1).

Across all the surveys, the median $\mathrm{CH}_{4}$ concentration in Lake Winnipeg was $24.10 \mathrm{nmol}$ $\mathrm{L}^{-1}$ (mean concentration of $41.6 \pm 68.1 \mathrm{nmol} \mathrm{L}^{-1}$ ) and ranged between $5.0-733.8 \mathrm{nmol} \mathrm{L}^{-1}$ (Table 2), while the median flux was $0.72 \mu \mathrm{mol} \mathrm{m} \mathrm{m}^{-2} \mathrm{~h}^{-1}$, and ranged between $0-78.4 \mu \mathrm{mol} \mathrm{m} \mathrm{m}^{-2}$ $\mathrm{h}^{-1}$ (mean flux: $2.79 \mu \mathrm{mol} \mathrm{m} \mathrm{m}^{-2} \mathrm{~h}^{-1}$ ). The $\mathrm{CH}_{4}$ concentration and flux data were right-skewed (Kolmogrov-Smirnov, $\alpha=0.05$ ), causing the median concentration to be lower than the mean (Table 2B; Fig.3). For this reason, we report mean and median values throughout, the former to allow for comparison with other studies.

The distribution of $\mathrm{CH}_{4}$ concentration at the surface is shown in Figure 2. $\mathrm{CH}_{4}$ concentrations ranged from $5.7-733.8 \mathrm{nmol} \mathrm{L}^{-1}$ in the south basin and $5.0-285.3 \mathrm{nmol} \mathrm{L} \mathrm{L}^{-1}$ in the north basin (Table 2), but the inter-basin $\mathrm{CH}_{4}$ concentration differences were not statistically significant (Wilcoxon Rank-Sum, $\alpha=0.05$ ). Similarly, we observed no significant difference between fluxes from the north and south basins. The highest $\mathrm{CH}_{4}$ concentrations and fluxes overall were measured near the mouth of the Red and Winnipeg Rivers (stations 4NS and 7, respectively), during summer 2018 (Electronic Supplementary Material (ESM) Table S1). We also observed generally higher $\mathrm{CH}_{4}$ concentrations in surface samples taken in nearshore areas and near to river outflows in both basins during all seasons (e.g., stations 4NS, 1, 2, 7, 7NS, 12NS identified in Fig. 2). The pattern is particularly strong in summer (2018 and 2019) and fall (2019). Interestingly, the $\mathrm{CH}_{4}$ concentration in surface samples at the station closest to the Winnipeg River (station 7) was particularly high in the summer of 2018 (733.8 nmol L-1), but not in the summer of $2019\left(142.8 \mathrm{nmol} \mathrm{L}^{-1}\right)$. Aside from the high $\mathrm{CH}_{4}$ concentrations near river mouths and nearshore stations, we also observed consistently high $\mathrm{CH}_{4}$ concentrations during 
all seasons at station W7, which is near the central part of the north basin and far from any river mouth. This station frequently had the highest concentrations of any stations sampled in the north basin (see ESM Table S1). Despite the likelihood of significant $\mathrm{CH}_{4}$ diffusion from sediments, vertical $\mathrm{CH}_{4}$ concentration gradients were weak, and differences between surface and bottom $\mathrm{CH}_{4}$ concentrations were not statistically significant (Wilcoxon Rank-Sum, $\alpha=0.05$ ).

We observed no statistically significant differences in annual $\mathrm{CH}_{4}$ concentrations or fluxes between 2018 and 2019 (Wilcoxon Rank-Sum, $\alpha=0.05$ ). The median flux was $1.13 \mu \mathrm{mol}$ $\mathrm{m}^{-2} \mathrm{~h}^{-1}$ (range: $0.46-70.1 \mu \mathrm{mol} \mathrm{m} \mathrm{m}^{-2} \mathrm{~h}^{-1}$, and mean of $3.0 \pm 10.1 \mu \mathrm{mol} \mathrm{m} \mathrm{m}^{-2} \mathrm{~h}^{-1}$ ) in 2018, and 0.55 $\mu \mathrm{mol} \mathrm{m} \mathrm{m}^{-2} \mathrm{~h}^{-1}$ (range: $0.0-78.4 \mu \mathrm{mol} \mathrm{m} \mathrm{m}^{-2} \mathrm{~h}^{-1}$, mean: $2.7 \pm 8.5 \mu \mathrm{mol} \mathrm{m}^{-2} \mathrm{~h}^{-1}$ ) in 2019 , indicating the lake was consistently emitting $\mathrm{CH}_{4}$ to the atmosphere during the open water season (Table 2A).

On seasonal time scales, we found no statistically significant differences in $\mathrm{CH}_{4}$ concentrations (Table 2; Wilcoxon Rank-Sum, $\alpha=0.05$ ). Despite the potential for $\mathrm{CH}_{4}$ accumulation under ice, mean winter $2018 \mathrm{CH}_{4}$ concentrations were not statistically different from other seasons (Wilcoxon Rank Sum, $\alpha=0.05$ ), but with a much smaller sample size $(n=8)$. In total, seven stations were consistently sampled at the surface depth during each cruise of our study. Of these, two stations exhibited the highest $\mathrm{CH}_{4}$ concentrations during winter (W12 and W13; see Fig. 2), whereas winter $\mathrm{CH}_{4}$ concentrations at stations W9 and W10 were lower than during any other cruise.

Maps of $\mathrm{CH}_{4}$ flux during each survey are shown in ESM Figure $\mathrm{S} 1$, while their distribution is shown in Figure 3 for each cruise. Unlike $\mathrm{CH}_{4}$ concentrations, we observed a clear seasonal trend for diffusive $\mathrm{CH}_{4}$ fluxes (Table 2, Fig. 3). $\mathrm{CH}_{4}$ fluxes during fall were significantly higher than during spring (Wilcoxon Rank Sum, p < 0.0001) and summer (Wilcoxon Rank Sum, p < 0.01). The largest diffusive fluxes were measured in fall 2019 (median: $2.4 \mu \mathrm{mol} \mathrm{m}{ }^{-2} \mathrm{~h}^{-1}$, range: $\left.0.0-78.4 \mu \mathrm{mol} \mathrm{m}^{-2} \mathrm{~h}^{-1}\right)$, and the lowest median flux in spring of $2019\left(0.3 \mu \mathrm{mol} \mathrm{m} \mathrm{m}^{-2} \mathrm{~h}^{-1}\right.$, range: $\left.0.0-13.4 \mu \mathrm{mol} \mathrm{m} \mathrm{m}^{-2} \mathrm{~h}^{-1}\right)$. This result largely reflects the variability in wind speeds among surveys (Table 1), with higher wind speeds during 2019 driving the largest diffusive fluxes despite lower surface $\mathrm{CH}_{4}$ concentrations. Fluxes for winter 2019 were not calculated, as ice cover was 
present, and flux is assumed to be zero. Our estimated annual $\mathrm{CH}_{4}$ flux during the open water season (May 01 - Nov 30) was $0.001 \mathrm{Tg} \mathrm{CH}_{4}-\mathrm{Cy}^{-1}$.

Dissolved oxygen concentrations during our surveys ranged from 7.0 to $12.6 \mathrm{mg} \mathrm{L}^{-1}$. A strong negative relationship between dissolved oxygen and dissolved $\mathrm{CH}_{4}\left(\mathrm{R}^{2}=0.93\right)$ was observed in the south basin during the summer of 2018 , but no clear relationship in the north basin (Fig. 4A). In fall of 2018, there was no clear relationship between $\mathrm{CH}_{4}$ and dissolved $\mathrm{O}_{2}$ in either basin (Fig. 4B). Dissolved $\mathrm{O}_{2}$ data was not available at the time of this publication for the 2019 surveys.

\section{Discussion}

Until very recently, there has been little published research on $\mathrm{CH}_{4}$ fluxes and dynamics in North America's Great Lakes, with recent exceptions including Lake Erie, Michigan, and Superior (Fernandez et al., 2020; Juong et al., 2019). Concentrations and fluxes reported in these studies appear in Table 3. Results presented here show that Lake Winnipeg is a source of $\mathrm{CH}_{4}$ to the atmosphere throughout the open water season, and concentrations show a high degree of horizontal spatial variability. The range in concentrations we observed in Lake Winnipeg is larger than that previously reported in other Canadian great lakes. Mean $\mathrm{CH}_{4}$ concentrations in both Lakes Erie and Winnipeg are higher than reported for Lakes Michigan and Superior (Table 3; Fernandez et al., 2020; Juong et al., 2019).

Lake Winnipeg is of similar area to Lake Erie $\left(\sim 23,750 \mathrm{~km}^{2}\right.$ to $\left.25,700 \mathrm{~km}^{2}\right)$ and, like Lake Erie in the 1960s (Beeton, 1963; Lu et al., 2010), Lake Winnipeg has undergone intense eutrophication since the late 1990s and early 2000s as the result of non-point source nutrient input (Environment Canada [EC] and Manitoba Water Stewardship [MWS], 2011). Previous work has established relationships between $\mathrm{CH}_{4}$ and high concentrations of phosphorus and chlorophyll- $a$ as a result of increased deposition of organic material to the sediments (Beaulieu et al., 2019). The productivity of a lake has also been linked to frequency of sub-surface anoxia in highly eutrophic lakes, which generally causes productive lakes to produce more $\mathrm{CH}_{4}$ relative to oligotrophic lakes (Beaulieu et al., 2019; Casper et al., 2000; Gonzalez-Valencia et al., 2014). Average $\mathrm{CH}_{4}$ concentrations and ranges in Lake Winnipeg were higher than reported for Lake Erie (5.7 - $733.8 \mathrm{nmol} \mathrm{L}^{-1}$ compared to 24.3 - $107.1 \mathrm{nmol} \mathrm{L}{ }^{-1}$; Table 3; Fernandez et al., 2020). 
Note that while mean hourly fluxes suggest the lakes to be similar in their emission characteristics (Lake Winnipeg: $2.8 \pm 9.2 \mu \mathrm{mol} \mathrm{m}^{-2} \mathrm{~h}^{-1}$, and Erie: $2.3 \mu \mathrm{mol} \mathrm{m}^{-2} \mathrm{~h}^{-1}$ ), the median flux from Lake Winnipeg in $2019\left(0.55 \mu \mathrm{mol} \mathrm{m}^{-2} \mathrm{~h}^{-1}\right)$ is much lower than the mean flux reported for Lake Erie (Table 3). Median values were not reported for Lake Erie. Despite generally higher $\mathrm{CH}_{4}$ concentrations, we infer that Lake Winnipeg is a lower annual source of $\mathrm{CH}_{4}$ as Lake Erie

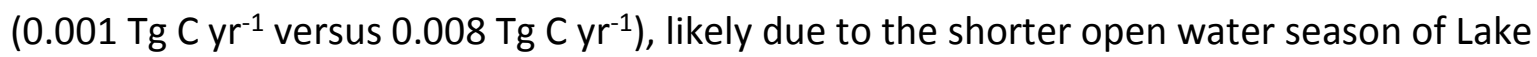
Winnipeg.

Striking in Table 3 is the large reported range of $\mathrm{CH}_{4}$ concentration for small boreal lakes (13 - 2,015 $\mathrm{nmol} \mathrm{L}^{-1}$; Bastviken et al., 2004) relative to Lake Winnipeg and the other North American Great Lakes. Rasilo et al. (2015) report dissolved $\mathrm{CH}_{4}$ (as partial pressure - $\mathrm{pCH}_{4}$ ) and $\mathrm{CH}_{4}$ fluxes for boreal lakes over a 6-year study. In their study summertime $\mathrm{pCH}_{4}$ averaged 191 $\mu$ atm (ranging between 6 and $3612 \mu \mathrm{atm}$ ) across 224 boreal lakes in Quebec. In that work water temperature was not provided so we cannot convert their partial pressures to $\mathrm{CH}_{4}$ concentration (nmol L-1) for comparison with this study. We converted our $\mathrm{CH}_{4}$ concentrations to partial pressures (following Warneck and Williams, 2012) and report that summertime $\mathrm{pCH}_{4}$ across both basins in Lake Winnipeg averaged $43.1 \mu$ atm (ranging between $5.2 \mu$ atm and 475.1 Matm) in 2018 and $21.1 \mu$ atm (ranging between $3.2 \mu$ atm and $92.4 \mu \mathrm{atm}$ ) in 2019, which based on average partial pressure, is respectively 4 and 9 times lower than in the boreal lakes studied in Quebec.

Mean rates of $\mathrm{CH}_{4}$ evasion from Lake Winnipeg appears to also be lower, and in some cases drastically so, relative to lakes surveyed in temperate, subarctic and boreal environments (Table 3; Bastviken et al., 2004; Fernandez et al., 2020; Juong et al., 2019; Rasilo et al., 2015). For small lakes $\left(<100 \mathrm{~km}^{2}\right.$ ) relationships have been observed (e.g., Rasilo et al., 2015) between summertime lake $\mathrm{pCH}_{4}$ concentration and flux and lake properties, including lake area, temperature, nutrient concentrations and CDOM. By comparison Lake Winnipeg is a very large water body that drains an enormous area from a regionally diverse catchment. Currently there are not sufficient data to explore which underlying factors drive spatial and temporal variability in both the $\mathrm{CH}_{4}$ concentration and flux within Lake Winnipeg, nor to explain differences between Lake Winnipeg's $\mathrm{CH}_{4}$ dynamics relative to studies cited in Table 3. Here we report a 
large degree of within lake variability in both the distribution of $\mathrm{CH}_{4}$ concentration and flux. This is perhaps not unexpected as the two basins that make up Lake Winnipeg can be very different in terms of their biogeochemical, biological, and physical properties (Levesque and Wassenaar, 2011; McCullough and Levesque, 2011; Page, 2011). Observed patterns in $\mathrm{CH}_{4}$ in Lake Winnipeg may thus reflect local forcing that at this time, with only five surveys of data, are difficult to extrapolate across the entire lake. Although we cannot definitively link $\mathrm{CH}_{4}$ variability to specific processes, our data may provide some insight into potential drivers of $\mathrm{CH}_{4}$ variability, and we discuss these below.

Some of the spatial variability in $\mathrm{CH}_{4}$ concentrations and fluxes we observed may be related to localized $\mathrm{CH}_{4}$ sources from rivers, and production near river mouths. As shown in Figure 2, generally higher $\mathrm{CH}_{4}$ concentrations were observed at nearshore stations in the south basin, and in proximity to river and marsh inflow. By comparison, $\mathrm{CH}_{4}$ concentrations in the north basin tended to be higher along the eastern shore, and at isolated hotspots in central portions of the basin. In 2018, in particular, we observed exceptionally high $\mathrm{CH}_{4}$ concentrations near the mouths of the Red River and Winnipeg River. Stations 1 and 2 are also downstream of an expansive coastal wetland at the southern edge of the lake. Freshwater marshes are among the largest natural $\mathrm{CH}_{4}$ sources (Kirschke et al., 2013), and thus may supply $\mathrm{CH}_{4}$ to the adjacent waters in Lake Winnipeg. Several rivers also drain into the eastern half of the north basin, namely the Poplar, Pigeon, Berens, and Bloodvein Rivers in the north basin, and the Winnipeg and Manigotogan River in the south basin (see Fig.1). These river inputs may explain the higher $\mathrm{CH}_{4}$ concentrations observed along the eastern half of the lake. Boreal lake systems have shown concentrations of $\mathrm{CH}_{4}$ to range from $13-2,015 \mathrm{nmol} \mathrm{L}^{-1}$ (Table 3; Bastviken et al., 2004), and these are similar to aquatic systems which lie to the east of Lake Winnipeg, suggesting rivers draining these watersheds are likely sources of dissolved $\mathrm{CH}_{4}$ to the lake. We also observed high $\mathrm{CH}_{4}$ concentrations during summer and fall 2019 near the Saskatchewan River mouth on the western edge of the north basin (Fig. 1; Fig. 2). The Saskatchewan River's catchment extends to the Rockies and thus runs east across the northern great plains underlain by dolomite and limestone, draining largely agricultural lands before entering the lake (Levesque and Page, 2011). The distribution of $\mathrm{CH}_{4}$ in the lake suggests that rivers import $\mathrm{CH}_{4}$ 
rich waters and are important in determining local variation of $\mathrm{CH}_{4}$ in the lake. These rivers also supply DOC to the lake (McCullough, 2001), which has been shown to have a positive relationship with $\mathrm{CH}_{4}$ concentrations (Bastviken et al., 2004). Additional work is required to better understand the role of these rivers in moderating the lake's $\mathrm{CH}_{4}$ dynamics.

A unique feature of Lake Winnipeg relative to other great lakes is that it is a cold polymictic lake, largely due to its shallowness and large fetch that aligns with prevailing winds. The strong mixing and associated ventilation likely contribute to the relatively low $\mathrm{CH}_{4}$ concentrations observed in our study by 1 ) providing a constant dissolved $\mathrm{O}_{2}$ supply to deep waters, which reduces $\mathrm{CH}_{4}$ production and promotes $\mathrm{CH}_{4}$ oxidation, and 2) promoting rapid $\mathrm{CH}_{4}$ outgassing, which reduces $\mathrm{CH}_{4}$ accumulation in the water column. Water column anoxia has never been observed, but dissolved oxygen concentrations are variable throughout the lake (McCullough, 2020; Wassenaar, 2012). Waters were well-oxygenated during our surveys $\left(\mathrm{O}_{2}>\right.$ $\sim 7.0 \mathrm{mg} \mathrm{L}^{-1}$ ), which may explain the lack of consistent negative correlation between $\mathrm{CH}_{4}$ and $\mathrm{O}_{2}$

(Fig. 4). This also suggests that sedimentary methanogenesis is the likely source of autochonous $\mathrm{CH}_{4}$ production in the lake. Water temperature did not seem to be related to $\mathrm{CH}_{4}$ concentration outside of the south basin in the summers, where water temperatures were generally higher and where we did see greater $\mathrm{CH}_{4}$ concentrations on average (Table 1, 2B).

Although mixing and ventilation may reduce $\mathrm{CH}_{4}$ production and storage, wave-induced sediment disturbance may enhance $\mathrm{CH}_{4}$ flux from sediments to the water column (Bastviken et al., 2008, 2004; Borrel et al., 2011). Previous studies of Lake Winnipeg have shown that sediment resuspension occurs frequently (Matisoff et al., 2017) and may thus be an important mechanism for $\mathrm{CH}_{4}$ release in shallow near-shore environments where wave action can disturb sediments. Indeed, we observed an inverse relationship between dissolved $\mathrm{CH}_{4}$ and water column depth in the south basin during $2018\left(R^{2}=0.60\right)$, indicating a potential tendency for $\mathrm{CH}_{4}$ concentration to increase with decreasing water column depth during the open water seasons. Conversely there was no obvious relationship between station depth and $\mathrm{CH}_{4}$ concentration for the north basin, although the several deep (W1 and W7), and shallow stations (12NS) are conspicuous by their high $\mathrm{CH}_{4}$ concentration relative to the average of the lake $\left(>41.6 \mathrm{nmol} \mathrm{L}^{-}\right.$ $\left.{ }^{1}\right)$. 
Another factor influencing $\mathrm{CH}_{4}$ variability may be differences in substrate quantity and quality for $\mathrm{CH}_{4}$ production. The lake experiences frequent and expansive algal blooms during the open water season, particularly in the north basin (Binding, 2020; Page, 2020; 2011). Algal biomass deposition specifically promotes higher rates of $\mathrm{CH}_{4}$ production compared to terrestrial plants (West et al., 2012), and limited research on Lake Erie has shown a strong relationship between and $\mathrm{CH}_{4}$ production and algal blooms (Fernandez et al., 2020). This has important implications for Lake Winnipeg, as a hypereutrophic lake that frequently experiences large scale algal blooms (Page, 2011). The frequency and intensity of these blooms are expected to escalate with higher temperatures and increased watershed nutrient runoff (Beaulieu et al., 2019, Fernandez et al., 2020). Recent work has also shown that marsh vegetation (i.e. Typha latifolia aka. Broadleaf Cattail) promotes much higher rates of $\mathrm{CH}_{4}$ production than the degradation of coniferous needles and deciduous tree leaves (Emilson et al. 2019), which may explain the high $\mathrm{CH}_{4}$ concentrations near the Netley-Libau Marsh in the southern end of the south basin (Fig. 2).

Given the prolonged ice cover during winter and corresponding suppression of $\mathrm{CH}_{4}$ evasion, we were surprised to find no evidence of $\mathrm{CH}_{4}$ accumulation in the water column during the winter sampling. However, our finding is consistent with observations of low $\mathrm{CH}_{4}$ concentrations under partial ice cover in Lake Erie (Fernandez et al., 2020). The average winter (2019) $\mathrm{CH}_{4}$ concentration (27.4 $\pm 20.8 \mathrm{nmol} \mathrm{L}^{-1}$; Table 2 ) is not significantly different (Wilcoxon Rank-Sum, $\alpha=0.05)$, than observed for the fall of 2018 and spring and summer in 2019 (23.87 \pm $14.5,31.7 \pm 41.8,32.7 \pm 28.4 \mathrm{nmol} \mathrm{L}^{-1}$, respectively; Fig. 3), and the spatial pattern of $\mathrm{CH}_{4}$ during the winter (Fig. 2) shows distinctive features that have also been identified in the warm season data sets, namely high $\mathrm{CH}_{4}$ concentration in the southern end of the lake and around W7 in the north basin. These two observations are surprising, given that the complete ice cover has been shown to promote the build-up of $\mathrm{CH}_{4}$ by preventing direct lake-air gas exchange (Greene et al., 2014; Michmerhuizen et al., 1996). The results suggest that 1) methane is actively oxidized over winter and production rates are reduced, which largely prevents large scale methane evasion during ice breakup, and 2) processes supporting the high $\mathrm{CH}_{4}$ at the stations identified above are possibly suppressed in the winter season. 


\section{Conclusions}

Our study revealed that Lake Winnipeg was consistently oversaturated with $\mathrm{CH}_{4}$ relative to the atmosphere, and a source of $\mathrm{CH}_{4}$ throughout the open water season. Despite its eutrophic state and frequent algal blooms, Lake Winnipeg does not emit or produce a large amount of dissolved $\mathrm{CH}_{4}$ per unit area compared to other lakes in the boreal regions of Canada and northern Europe (Bastviken et al., 2011; Casper et al, 2000; Demarty et al., 2010; Huutunen et al, 2003; Kankaala et al., 2013; Table 3). We attribute this to the lake's large fetch and shallow depth, which combine to ventilate the lake, adding $\mathrm{O}_{2}$ and limiting $\mathrm{CH}_{4}$ accumulation in the water column. The low emission intensity and large drainage basin area suggest that $\mathrm{CH}_{4}$ emissions from Lake Winnipeg only modestly offset the terrestrial greenhouse gas sink. However, recent work suggests lake methane emissions could increase in response to eutrophication (Beaulieu et al., 2019), underscoring the importance of continued $\mathrm{CH}_{4}$ monitoring in Lake Winnipeg.

We identified several sites with persistently high dissolved $\mathrm{CH}_{4}$ concentrations near the mouths of the Red and Winnipeg Rivers. We found no consistent relationship between dissolved $\mathrm{O}_{2}$ and $\mathrm{CH}_{4}$ concentration or flux, and no evidence for significant $\mathrm{CH}_{4}$ accumulation under ice during winter. Further research should be done on $\mathrm{CH}_{4}$ in Lake Winnipeg to identify causes of the patterns and hotspots, whether they are related to seeps, riverine input, or produced through in-situ process of methanogenesis, quantify water column oxidation rates, as well as to measure possible ebullitive and plant-mediated fluxes. 


\section{Acknowledgements}

Research funded by NSERC Discovery Grant (to TP), Postdoctoral Fellowship (to DC and CM) and USRA Programs. We are grateful to Karen Scott and the Lake Winnipeg Research Consortium (LWRC), as well as the captain and crew of the MV Namao. Additional sample collection and analysis was made possible with help of Claire Herbert and Greg McCullough from the Centre for Earth Observation Science (CEOS) at the University of Manitoba. We are grateful to both Y. Yezhova and A. Soloway of CEOS for logistical and sampling support, and for research support associated with the processing of $\mathrm{CH}_{4}$ samples at Philippe Tortell's lab at UBC. Some of the data presented herein were collected on board the M/V Namao with logistical and field assistance provided by the LWRC's and ECCC's Science Programs, as well as the Province of Manitoba's Agriculture and Resource Development. We are grateful to Manitoba Hydro who provided summer student support for R.R.M. over a portion of the 2019 field season. 


\section{References}

Bastviken, D., Cole, J.J., Pace, M.L., Tranvik, L., 2004. Methane emissions from lakes:

Dependence of lake characteristics, two regional assessments, and a global estimate. Global Biogeochem Cycles. 18, 1-12. doi:10.1029/2004gb002238.

Bastviken, D., Cole, J.J., Pace, M.L., Van de Bogert, M.C., 2008. Fates of methane from different lake habitats: Connecting whole-lake budgets and $\mathrm{CH} 4$ emissions. J. Geophys. Res. 113, 1-13. doi:10.1029/2007jg000608.

Bastviken, D., Tranvik, L. J., Downing, J. A., Crill, P. M. \& Enrich-Prast, 2011. Freshwater methane emissions offset the continental carbon sink. Science. 331, 50. doi: 10.1126/science. 1196808

Beaulieu, J.J., DelSontro, T., Downing, J.A., 2019. Eutrophication will increase methane emissions from lakes and impoundments during the $21^{\text {st }}$ century. Nat. Commun. 10, 1-5. doi:10.1038/s41467-019-09100-5

Beeton, A. M., 1963. Limnological survey of Lake Erie 1959 and 1960 (No. 6, pp. 0-32). Great Lakes Fishery Commission.

Binding, C., 2020. State of Lake Winnipeg: $2^{\text {nd }}$ Edition. Environment and Climate Change Canada and Manitoba Agriculture and Research Division. 90-93. https://gov.mb.ca/water/pubs/water/lakes-beaches-rivers/state_lake_wpg_report_tech.pdf

Bogard, M.J., del Giorgio, P.A., Boutet, L., Garcia Chaves, M.C., Prairie, Y.T., Merante, A., Derry., A.M., 2014. Oxic water column methanogenesis as a major component of aquatic $\mathrm{CH}_{4}$ fluxes. Nat Commun. 5, 1-9. doi: 10.1038/ncomms6

Borrel, G., Jezequel, D., Biderre-Petit, C., Morel-Desrosiers, N., Morel, J.P., Peyret, P., Fonty, G., Lehours, A.C., 2011. Production and consumption of methane in freshwater lake ecosystems. Res. J. Microbiol. 162, 832-847. doi:10.1016/j.resmic.2011.06.004

Capelle, D.W., Dacey, J.W., Tortell, P.D., 2015. An automated, high through-put method for accurate and precise measurements of dissolved nitrous-oxide and methane concentrations in natural waters. Limnol. Oceanogr-Meth. 13, 345-355. doi: 10.1002/lom3.10029.

Casper, P., Maberly, S.C., Hall, G.H., Finlay, B.J., 2000. Fluxes of methane and carbon dioxide from a small productive lake to the atmosphere. Biogeochemistry. 49,1-19. doi: 10.1023/A:1006269900174 
Craig, H. and Hayward, T., 1987. Oxygen supersaturation in the ocean: biological versus physical contributions. Science. 235, 199-202. doi: 10.1126/science.235.4785.199

Delavau, C., \& Lee, M., 2020. State of Lake Winnipeg: $2^{\text {nd }}$ Edition. Environment and Climate Change Canada and Manitoba Agriculture and Research Division. 17-25. https://gov.mb.ca/water/pubs/water/lakes-beaches-rivers/state_lake_wpg_report_tech.pdf

DelSontro, T., Boutet, L., St-Pierre, A., del Giorgio, P.A., Prairie, Y.T., 2016. Methane ebullition and diffusion from northern ponds and lakes regulated by the interaction between temperature and system productivity. Limnol. Oceanogr. 61, S62-S77. doi: 10.1002/lno.10335.

Demarty, M., Bastien, J., Tremblay, A., 2011. Annual follow-up of gross diffusive carbon dioxide and methane emissions from a boreal reservoir and two nearby lakes in Quebec, Canada. Biogeosciences. 8, 41-53. doi:10.5194/bg-8-41-2011.

Dlugokencky, E.J., Crotwell, A.M., Mund, J.W., Crotwell, M.J., Thoning, K.W., 2020. Atmospheric Methane Dry Air Mole Fractions from the NOAA GML Carbon Cycle Cooperative Global Air Sampling Network, 1983-2019, Version: 2020-07, doi: 10.15138/VNCZ-M766.

Emilson, E.J.S., Carson, M.A., Yakimovich, K.M., Osterholz, H., Dittmar, T., Gunn, J.M., Mykytczuk, N.C.S., Basiliko, N., Tanentzap, A.J., 2018. Climate-driven shifts in sediment chemistry enhance methane production in northern lakes. Nat. Comm. 9, 1-6. doi: 10.1038/s41467-018-04236-2.

Environment and Climate Change Canada and Manitoba Agriculture and Research Division. 2020. State of Lake Winnipeg $2^{\text {nd }}$ Edition, 1-195. https://gov.mb.ca/water/pubs/water/lakes-beaches-rivers/state_lake_wpg_report_tech.pdf

Environment Canada and Manitoba Water Stewardship, 2011. State of Lake Winnipeg: 1999 2007, 1-222. http://hdl.handle.net/1993/23915

Fernandez, J.M., Townsend-Small, A., Zastepa, A., Watson, S.B., Brandes, J.A., 2020. Methane and nitrous oxide measured throughout Lake Erie indicate highest emissions from the eutrophic Western Basin. Journal of Great Lakes Research 46: 1604-1614. doi: 10.1016/j.jglr.2020.09.011.

Gonzalez-Valencia, R., Sepulveda-Jauregui, A., Martinez-Cruz, K., Hoyos-Santillan, J., Dendoovan, L., Thalasso, F., 2014. Methane emissions from Mexican freshwater bodies: 
correlations with water pollution. Hydrobiologia. 721, 9-22. doi: 10.1007/s10750-013 $1632-4$.

Gosink, T. A., Pearson, J. G. and Kelly, J. J., 1976. Gas movement through sea-ice. Nature. 263, 41-42. doi: 10.1038/263041a0

Greene, S., Anthony, W., Archer, D., Sepulveda-Jauregui, A., Martinez-Cruz, K., 2014. Modelling the impediment of methane ebullition bubbles by seasonal lake ice. Biogeosciences. 11, 6791-6811. doi:10.5194/bg-11-6791-2014.

Hemminsen, E., 1959. Permeation of gases through ice. Tellus. 11, 355-359. doi: 10.1111/j.2153-3490.1959.tb00041.x

Huttunen, J.T., Alm, J., Liikanen, A., Juutinen, S., Larmola, T., Hammar, T., Silvola, J., Martikainen, P.J., 2003. Fluxes of methane, carbon dioxide and nitrous oxide in boreal lakes and potential anthropogenic effects on the aquatic greenhouse gas emissions. Chemosphere. 52, 609-621. doi:10.1016/S0045-6535(03)00243-1.

IPCC: Climate Change 2013: The Physical Science Basis. Contribution of Working Group I to the Fifth Assessment Report of the Intergovernmental Panel on Climate Change 9(2013) [Stocker, T.F., D. Qin, G.-K. Plattner, M. Tignor, S.K. Allen, J. Boschung, A., Nauels, Y. Xia, V. Bex and P.M. Midgley (eds.)]. Cambridge University Press, Cambridge, United Kingdom and New York, NY, USA, 1535 pp.

Jähne, B., Heinz, G., Dietrich, W. 1987. Measurement of the diffusion coefficients of sparingly soluble gases in water with a modified barrier method. J. Geophys. Res. 92,10767-10776. doi:10. 1029/ JC092iC10p10767.

Juong D., Leonte, M., \& Kessler, J.D., 2019. Methane Sources in the Waters of Lake Michigan and Lake Superior as Revealed by Natural Radiocarbon Measurements. J. Geophys. Res. 46, 5436-5444. doi: 10.1029/2019GL082531.

Kankaala, P., Huotari, J., Tulonen, T., Ojala, A., 2013. Lake-size dependent physical forcing drives carbon dioxide and methane effluxes from lakes in a boreal landscape. Limnol. Oceanogr. 58,1915-1930. doi:10.4319/lo.2013.58.6.1915.

Kirschke, S., Bousquet, P., Ciasis, P., Saunois, M., Canadell, J.G., Dlugokencky, E.J., Bergamaschi, P., Bergmann, D., Blake, D.R., Bruhwiler, L., Cameron-Smith, P.,Castaldi, S., Chevallier, F., Feng, L., Fraser, A., Heimann, M., Hodson, E.L., 
Houweling, S., Josse, B., Fraser, P.J.Zeng, G., 2013. Three decades of global methane sources and sinks. Nat. Geosci. 6, 813-824. doi: 10.1038/NGEO1955.

Levesque, L., \& Page, E., 2011. State of Lake Winnipeg: 1999-2007. Environment Canada and Manitoba Water Stewardship. 6-18. http://hdl.handle.net/1993/23915

Levesque, L., \& Wassenaar, L., 2011. State of Lake Winnipeg: 1999-2007. Environment Canada and Manitoba Water Stewardship. 38-59. http://hdl.handle.net/1993/23915

Lu, Y., Meyers, P., Eadie, B., Robbins, J., 2010. Carbon cycling in Lake Erie during cultural eutrophication over the last century inferred from stable carbon isotope composition of sediments. J. Paleolimnol. 43(2), 261-272. doi:10.1007/s10933-009-9330y.

Manning, C. C., Stanley, R. H. R., Nicholson, D. P., Loose, B., Lovely, A., Schlosser, P., and Hatcher, B. G., 2019. Changes in gross oxygen production, net oxygen production, and air-water gas exchange during seasonal ice melt in Whycocomagh Bay, a Canadian estuary in the Bras d'Or Lake system. Biogeosciences. 16, 3351-3376. doi:10.5194/bg16-3351-2019.

Matisoff, G., Watson, S.B., Guo, J., Duewiger, A., Steely, R., 2017. Sediment and nutrient distribution and resuspension in Lake Winnipeg. Sci. Total Environ. 575, 173-186. doi:10.1016/j.scitotenv.2016.09.227.

McCullough, G., and Levesque, L., 2011. State of Lake Winnipeg: 1999-2007. Environment Canada and Manitoba Water Stewardship. 28-59. http://hdl.handle.net/1993/23915

McCullough, G., 2020. State of Lake Winnipeg: $2^{\text {nd }}$ Edition. Environment and Climate Change Canada and Manitoba Agriculture and Research Division. 26-42. https://gov.mb.ca/water/pubs/water/lakes-beaches-rivers/state_lake_wpg_report_tech.pdf

Michmerhuizen, C.M., Striegl, R.G., McDonald, M.E., 1996. Potential methane emission from north Temperate lakes following ice melt. Limnol. Oceanogr. 41, 985-991.

Page, E., 2011. State of Lake Winnipeg: 1999-2007. Environment Canada and Manitoba Water Stewardship. 60-80. http://hdl.handle.net/1993/23915

Page, E., 2020. State of Lake Winnipeg: $2^{\text {nd }}$ Edition. Environment and Climate Change Canada and Manitoba Agriculture and Research Division. 56-68. https://gov.mb.ca/water/pubs/water/lakes-beaches-rivers/state_lake_wpg_report_tech.pdf 
Peeters, F., Encinas Fernandez, F., \& Hofmann, H., 2019. Sediment fluxes rather than oxic methanogenesis explain diffusive $\mathrm{CH}_{4}$ emissions from lakes and reservoirs. Sci. Rep. 9, 1-10. doi:10.1038/s41598-018-36530-w

QGIS Development Team, 2020. QGIS Geographic Information System. Open Source Geospatial Foundation Project. http://qgis.osgeo.org

Rasilo, T., Prairie, Y.T., Del Giorgio, P.A., 2015. Large-scale patterns in summer diffusive $\mathrm{CH}_{4}$ fluxes across boreal lakes, and contribution to diffusive $\mathrm{C}$ emissions. Glob Chang Biol. 21: 1124-1139. doi: 10.1111/gcb.12741

Smith, R., 2020. State of Lake Winnipeg: $2^{\text {nd }}$ Edition. Environment and Climate Change Canada and Manitoba Agriculture and Research Division. 10-16. https://gov.mb.ca/water/pubs/water/lakes-beaches-rivers/state_lake_wpg_report_tech.pdf

Statistics Canada, 2018. Geography. Archived Information. Statistics Canada; [July 30, 2020]. https://www150.statcan.gc.ca/n1/pub/11-402-x/2011000/chap/geo/geo-eng.htm

Todd, B.J., Lewis, C.F.M., Nielsen, E., Thorleifson, L.H., Bezys, R.K., Weber, W., 1997. Lake Winnipeg: geological setting and sediment seismostratigraphy. J. Paleolimnol. 19, 215 244.

Wanninkhof, R., 2014. Relationship between wind speed and gas exchange over the ocean revisited. Limnol Oceanogr-Meth. 12, 351-362. doi: 10.4319/lom.2014.12.351.

Wassenaar, L.I., 2012. Dissolved oxygen status of Lake Winnipeg: Spatio-temporal and isotopic $\left(\delta^{18} \mathrm{O}_{-} \mathrm{O}_{2}\right)$ patterns. J Great Lakes Res. 38, 123-134. doi:10.1016/j.jglr.2010.12.011.

Warneck, P., \& J. Williams. 2012. The Atmospheric Chemist's Companion: Numerical Data for use in the Atmospheric Sciences. Springer Sci. \& Business Media.

Watchorn, K. E., Goldsborough, L.G., Wrubleski, D.A., Mooney, B.G. 2012. A hydrogeomorphic inventory of coastal wetlands of the Manitoba Great Lakes: Lakes Winnipeg, Manitoba, and Winnipegosis. J Great Lakes Res. 38, 115-122. doi: 10.1016/j.jglr.2011.05.008

Watchorn, E., 2020. State of Lake Winnipeg: $2^{\text {nd }}$ Edition. Environment and Climate Change Canada and Manitoba Agriculture and Research Division. 1-9. https://gov.mb.ca/water/pubs/water/lakes-beaches-rivers/state_lake_wpg_report_tech.pdf 
West, W.E., Coloso, J.J., Jones, S.E., 2012. Effects of algal and terrestrial carbon on methane production rates and methanogen community structure in a temperate lake sediment. Freshw. Biol. 57, 949-955. doi:10.1111/j.1365-2427.2012.02755.x.

Wiebe, B., 2020. State of Lake Winnipeg: $2^{\text {nd }}$ Edition. Environment and Climate Change Canada and Manitoba Agriculture and Research Division. 69-82. https://gov.mb.ca/water/pubs/water/lakes-beaches-rivers/state_lake_wpg_report_tech.pdf

Wiesenburg, D. A., and Guinasso Jr, N. L., 1979. Equilibrium solubilities of methane, carbon monoxide, and hydrogen in water and sea water. J. Chem Eng Data. 24, 356-360. doi: 10.1021/je60083a006

Wolff, E., and Spahni, R., 2007. Methane and nitrous oxide in the ice core record. Philos. Trans. Royal Soc. 365, 1775-1792. doi: 10.1098/rsta.2007.2044. 


\section{Tables}

Table 1: Wind speed $\left(\mathrm{m} \mathrm{s}^{-1}\right)$ and water temperature $\left({ }^{\circ} \mathrm{C}\right)$ in Lake Winnipeg across five surveys, excluding winter 2019. Data is split into north basin (NB) and south basin (SB).

\section{Wind Speed $\left(\mathrm{m} \mathrm{s}^{-1}\right) \quad$ Water Temp $\left({ }^{\circ} \mathrm{C}\right)$}

\begin{tabular}{|c|c|c|c|c|c|c|c|c|}
\hline Season & Basin & Year & Mean & Median & $\begin{array}{l}\text { Standard } \\
\text { Deviation }\end{array}$ & Mean & Median & $\begin{array}{l}\text { Standard } \\
\text { Deviation }\end{array}$ \\
\hline \multirow[t]{2}{*}{ Spring } & NB & 2019 & 3.4 & 2.7 & 2.1 & 8.3 & 7.4 & 2.7 \\
\hline & SB & 2019 & 3.4 & 2.7 & 2.3 & 13.4 & 12.8 & 2.3 \\
\hline \multirow[t]{4}{*}{ Summer } & NB & 2018 & 4.9 & 4.6 & 3 & 19.5 & 19.6 & 1.5 \\
\hline & & 2019 & 2.6 & 2.5 & 1.3 & 20 & 19.9 & 1.6 \\
\hline & $S B$ & 2018 & 4.9 & 5.1 & 2.9 & 20.2 & 20.2 & 0.3 \\
\hline & & 2019 & 3.4 & 3.9 & 1.9 & 22 & 22.1 & 0.7 \\
\hline \multirow[t]{4}{*}{ Fall } & NB & 2018 & 5.4 & 5.7 & 1.6 & 8.3 & 7.9 & 1.6 \\
\hline & & 2019 & 6 & 5.4 & 4.1 & 15.4 & 15.6 & 0.3 \\
\hline & SB & 2018 & 6.8 & 6.2 & 3.6 & 7.7 & 7.6 & 4.5 \\
\hline & & 2019 & 5.1 & 4.6 & 2.4 & 12.6 & 11 & 3.3 \\
\hline
\end{tabular}


Table 2: Average, median, standard deviation, maximum, minimum, and sample size (N), for (A) diffusive $\mathrm{CH}_{4}$ flux $\left(\mu m o l \mathrm{CH}_{4} \mathrm{~m}^{-2} \mathrm{~h}^{-1}\right)$ and (B) concentration ( $\mathrm{nmol} \mathrm{L}^{-1}$ ) respectively. NB and SB denote north and south basins of Lake Winnipeg. No flux estimate was calculated for winter 2019 as ice cover was present. Data from both surface and bottom samples (when available) were used.

\begin{tabular}{|c|c|c|c|c|c|c|c|c|c|c|c|c|c|c|}
\hline \multirow[b]{2}{*}{ Cruise } & \multirow[b]{2}{*}{ Year } & \multirow[b]{2}{*}{ Basin } & \multicolumn{6}{|c|}{$\mathrm{CH}_{4}$ concentration $\left(\mathrm{nmol} \mathrm{L}{ }^{-1}\right.$ ) } & \multicolumn{6}{|c|}{$\mathrm{CH}_{4}$ flux $\left(\mu \mathrm{mol} \mathrm{m}{ }^{-2} \mathrm{~h}^{-1}\right)$} \\
\hline & & & Mean & Median & $\begin{array}{l}\text { Standard } \\
\text { Deviation }\end{array}$ & Maximum & Minimum & $N$ & Average & Median & $\begin{array}{l}\text { Standard } \\
\text { Deviation }\end{array}$ & Maximum & Minimum & $\mathrm{N}$ \\
\hline \multirow[t]{3}{*}{ Spring } & 2019 & NB & 24.0 & 22.3 & 7.5 & 48.7 & 9.5 & 33 & 0.6 & 0.3 & 0.7 & 2.7 & 0.0 & 24 \\
\hline & 2019 & SB & 48.6 & 19.3 & 73.6 & 282.5 & 15.4 & 15 & 2.4 & 0.4 & 4.4 & 13.4 & 0.0 & 10 \\
\hline & 2019 & Lake & 31.7 & 22.0 & 42.2 & 282.5 & 9.5 & 48 & 1.1 & 0.3 & 2.5 & 3.2 & 0.0 & 34 \\
\hline \multirow[t]{6}{*}{ Summer } & 2018 & NB & 43.2 & 32.1 & 43.4 & 217.2 & 8.4 & 28 & 1.9 & 1.3 & 3.1 & 13.4 & 0.0 & 19 \\
\hline & 2018 & SB & 122.4 & 32.7 & 230.3 & 733.8 & 8.1 & 12 & 11.6 & 1.4 & 26.2 & 70.8 & 0.4 & 7 \\
\hline & 2018 & Lake & 67.0 & 32.1 & 132.7 & 733.8 & 8.1 & 40 & 4.5 & 1.3 & 13.8 & 70.8 & 0.0 & 26 \\
\hline & 2019 & NB & 29.8 & 24.2 & 23.6 & 126.7 & 5.0 & 30 & 0.4 & 0.4 & 0.4 & 1.2 & 0.0 & 22 \\
\hline & 2019 & SB & 39.8 & 21.1 & 39.1 & 142.8 & 14.7 & 12 & 2.5 & 0.7 & 4.3 & 12.2 & 0.0 & 11 \\
\hline & 2019 & Lake & 32.7 & 21.9 & 28.7 & 142.8 & 5.0 & 42 & 1.1 & 0.4 & 2.6 & 12.2 & 0.0 & 33 \\
\hline \multirow[t]{6}{*}{ Fall } & 2018 & NB & 26.2 & 19.7 & 15.9 & 73.7 & 10.2 & 26 & 1.1 & 1.0 & 0.8 & 3.2 & 0.1 & 18 \\
\hline & 2018 & SB & 16.7 & 13.8 & 7.5 & 30.7 & 10.3 & 9 & 1.4 & 1.4 & 1.0 & 2.5 & 0.2 & 4 \\
\hline & 2018 & Lake & 23.8 & 18.5 & 14.7 & 73.7 & 10.2 & 35 & 1.2 & 1.1 & 0.9 & 3.2 & 0.1 & 22 \\
\hline & 2019 & NB & 52.5 & 43.2 & 54.1 & 285.3 & 12.1 & 31 & 7.4 & 2.3 & 16.3 & 78.4 & 0.0 & 23 \\
\hline & 2019 & SB & 60.8 & 41.1 & 64.3 & 203.5 & 11.5 & 13 & 2.9 & 2.4 & 1.9 & 6.4 & 0.8 & 7 \\
\hline & 2019 & Lake & 54.9 & 42.1 & 56.7 & 285.3 & 11.5 & 44 & 6.4 & 2.4 & 14.3 & 78.4 & 0.0 & 30 \\
\hline \multirow[t]{3}{*}{ Winter } & 2019 & NB & 28.4 & 23.0 & 15.5 & 50.4 & 10.2 & 6 & & & & & & \\
\hline & 2019 & SB & 25.4 & 6.5 & 33.4 & 63.9 & 5.7 & 3 & & & & & & \\
\hline & 2019 & Lake & 27.4 & 21.3 & 20.8 & 63.9 & 5.7 & 9 & & & & & & \\
\hline
\end{tabular}


Table 3: Comparison of dissolved $\mathrm{CH}_{4}$ concentration and diffusive flux with other lakes.

Concentrations are shown as ranges, fluxes are shown as mean \pm 1 standard deviation where data are available. Annual fluxes were derived using mean values, while annual flux for Lake Winnipeg derived using median values is shown in parentheses. Compiled using data from ${ }^{1}$ Bastviken et al, (2004); 2Bastviken et al, (2009); ${ }^{3}$ Fernandez et al, (2019); ${ }^{4}$ Juong et al, (2019); and ${ }^{5}$ Rasilo et al., (2015).

\begin{tabular}{|c|c|c|c|c|}
\hline \multirow[b]{2}{*}{ Lake } & \multirow{2}{*}{$\begin{array}{r}\text { Surface Area } \\
\left(\mathrm{km}^{2}\right) \\
\end{array}$} & \multirow{2}{*}{$\begin{array}{r}\mathrm{CH}_{4} \\
\left(\mathrm{nmol} \mathrm{L}^{-1}\right) \\
\end{array}$} & \multicolumn{2}{|c|}{ Diffusive $\mathrm{CH}_{4}$ flux } \\
\hline & & & $\left(\mu \mathrm{mol} \mathrm{CH}_{4} \mathrm{~m}^{-2} \mathrm{~h}^{-1}\right)$ & $\left(\mathrm{Tg} \mathrm{CH}_{4} \mathrm{Y}^{-1}\right)$ \\
\hline & & & & 0.0039 \\
\hline Winnipeg $^{+}$ & 23,750 & $5.0-733.8$ & $2.8 \pm 9.2$ & $(0.0014)$ \\
\hline Erie $^{3}$ & 25,657 & $24.3-107.1$ & 2.3 & 0.008 \\
\hline Superior + Michigan ${ }^{4}$ & 140,103 & $3.5-60.0$ & & \\
\hline Small Boreal Lakes ${ }^{1}$ & & $13-2,015$ & $0.8-417.8$ & \\
\hline & 35.2 & & & \\
\hline Lakes in Quebec ${ }^{5++}$ & $(0.01-5,030)$ & & $40.3 \pm 91.7$ & \\
\hline $\begin{array}{l}\text { Lakes between 54-66 } \\
\operatorname{deg} N^{2}\end{array}$ & $1,533,084$ & & 5.1 & 1.1 \\
\hline Lakes between 25-54 & & & & \\
\hline $\operatorname{deg} N^{2}$ & $1,330,264$ & & 25.7 & 4.8 \\
\hline
\end{tabular}




\section{Figure Captions}

Figure 1: Lake Winnipeg. The location of Lake Winnipeg within Canada is shown on the inset, with major rivers, cities and communities marked on the main map.

Figure 2: Surface concentrations of Lake Winnipeg dissolved $\mathrm{CH}_{4}$, in nmol $\mathrm{L}^{-1}$. Scale is logarithmic, base 3, to account for the wide range of concentrations. 2019 had a greater sampling density than 2018. The Lake Winnipeg station map located as an inset. Not all stations were sampled each cruise. "NS" denotes "nearshore." All stations sampled were at minimum at the "surface" depth, $1 \mathrm{~m}$ below the lake surface, and "W" stations were sampled at both surface depth and "bottom," or $1 \mathrm{~m}$ above the lake bottom. Map generated using QGIS (2020).

Figure 3: Lake $\mathrm{CH}_{4}$ concentration in nmol L-1 (a), and $\mathrm{CH}_{4}$ flux in $\mu \mathrm{mol} \mathrm{m}^{-2} \mathrm{~h}^{-1}$ (b). Extreme outliers ( $>400 \mathrm{nmol} \mathrm{L}^{-1}$ for concentration and $>17 \mu \mathrm{mol} \mathrm{m}^{-2} \mathrm{~h}^{-1}$ for flux) have been removed to allow better display variability in the data set. No flux estimates were made for winter 2019, as ice cover was present. Data is split into the north basin, and south basin for each cruise sampled.

Figure 4: Summer 2018 (4A) and fall 2018 (4B) dissolved oxygen concentrations in $\mathrm{mg} \mathrm{L}^{-1}$ and $\mathrm{CH}_{4}$ in $\mathrm{nmol} \mathrm{L}{ }^{-1}$. $\mathrm{R}^{2}$ values from 2 nd order polynomial trendlines for south and north basin respectively in summer 2018 are 0.93 and 0.22 , and in fall 2018, 0.16 and 0.12 for north and south basins respectively. More variability is seen for both $\mathrm{CH}_{4}$ and $\mathrm{O}_{2}$ in the summer season than fall. Log base 10 is used on the y-axis. 


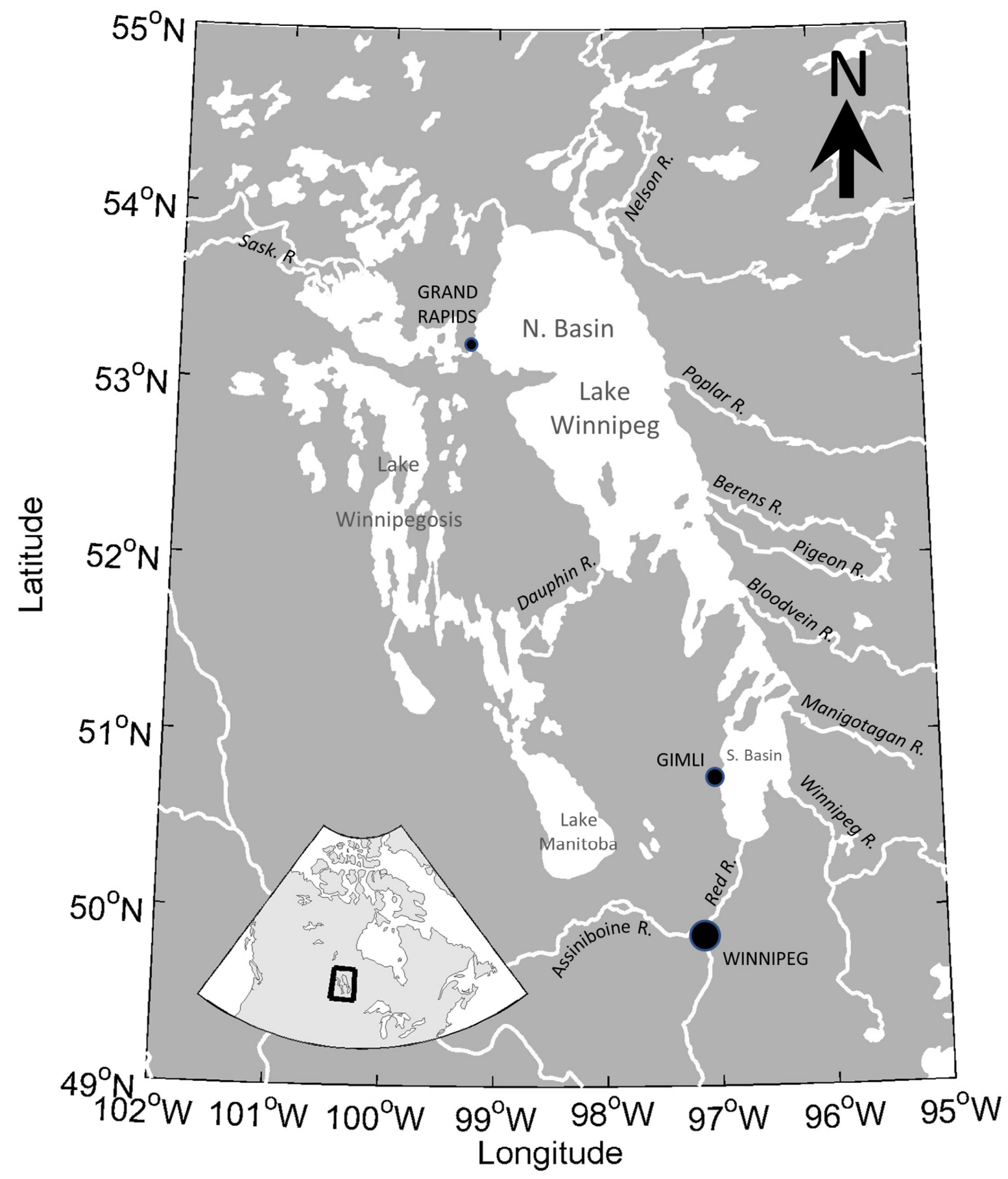


Legend

Dissolved Methane (nmol L^-1) 3-9

9- 97

$27-81$

$81-243$

- $243-729$

- Stations

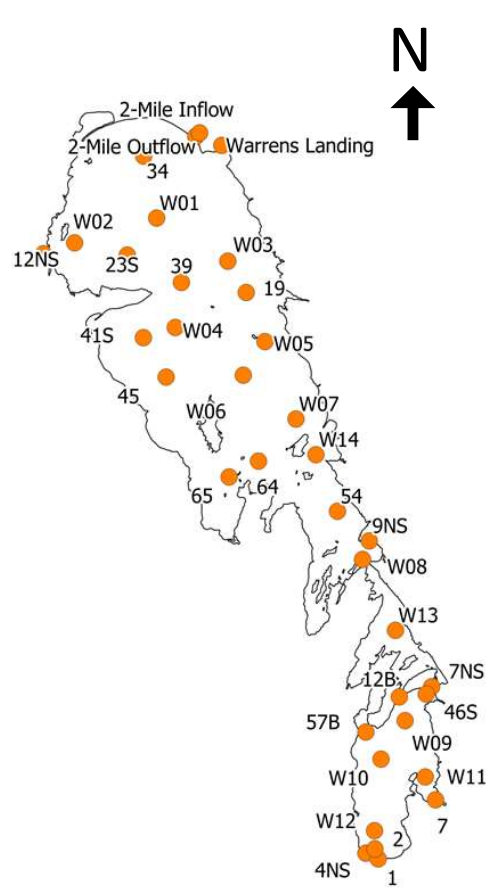

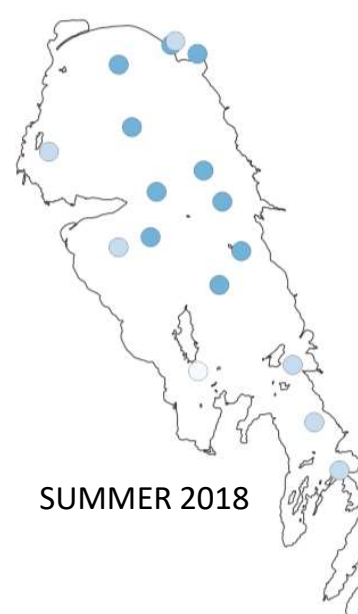
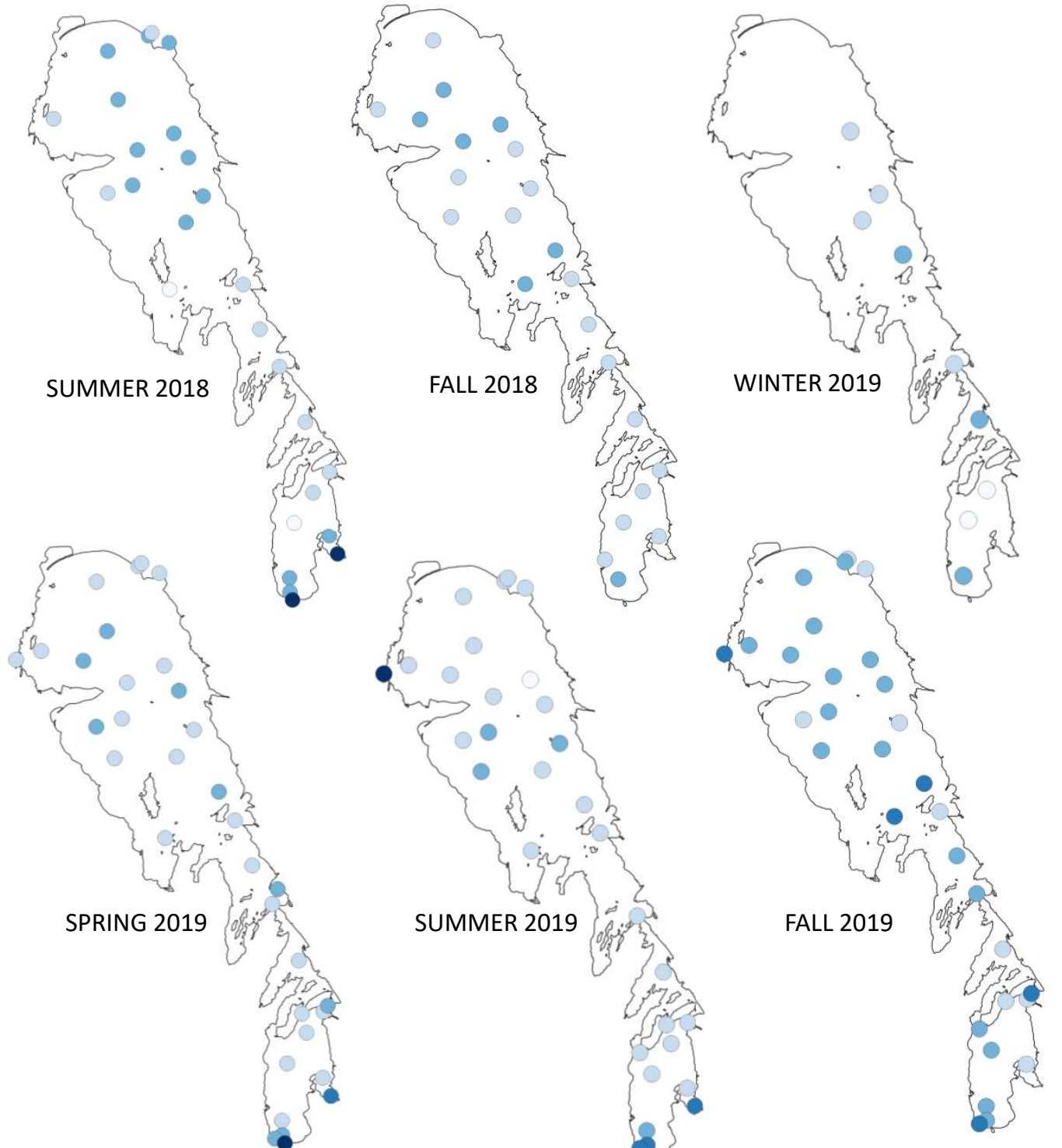


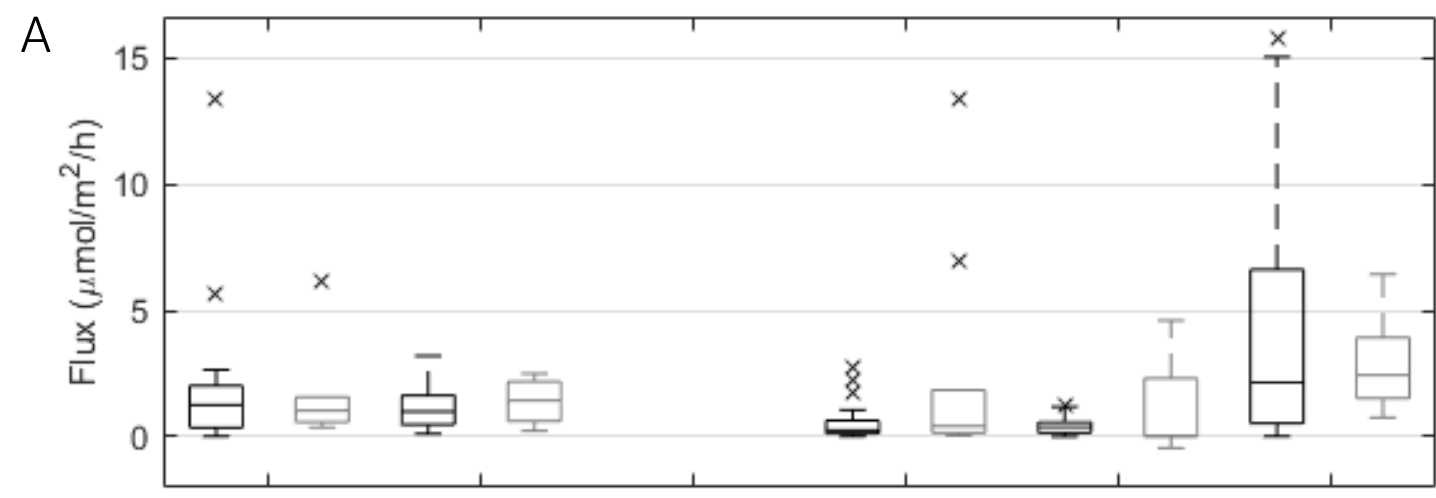

B

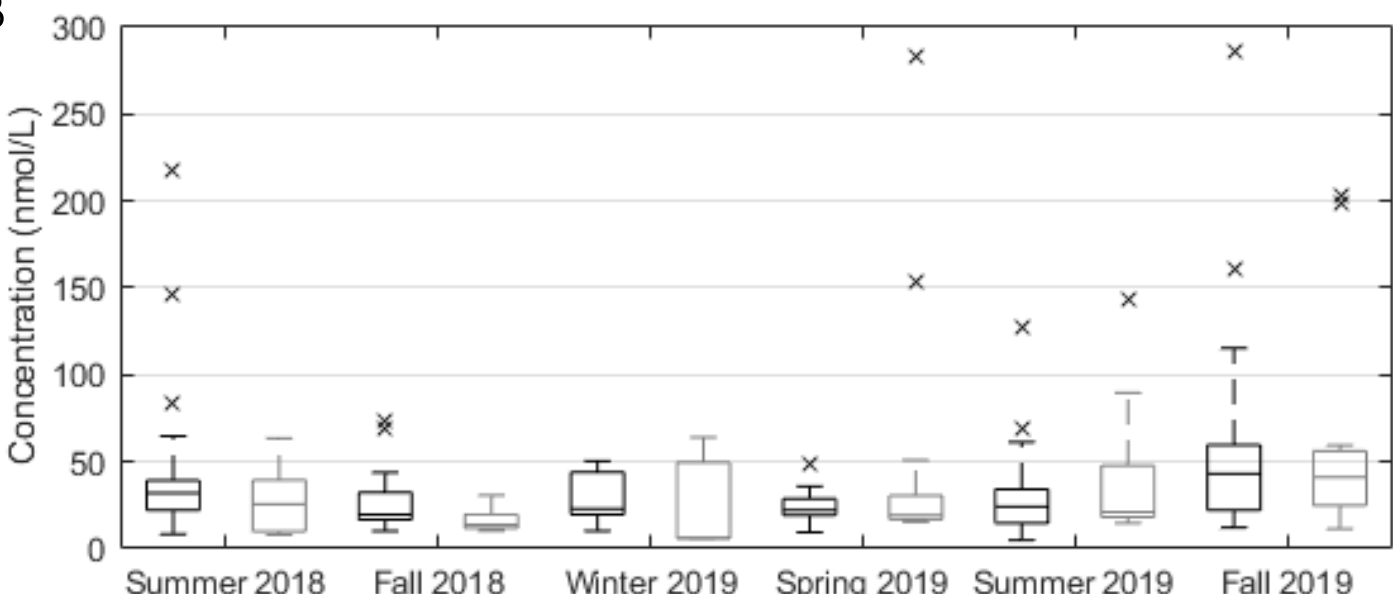



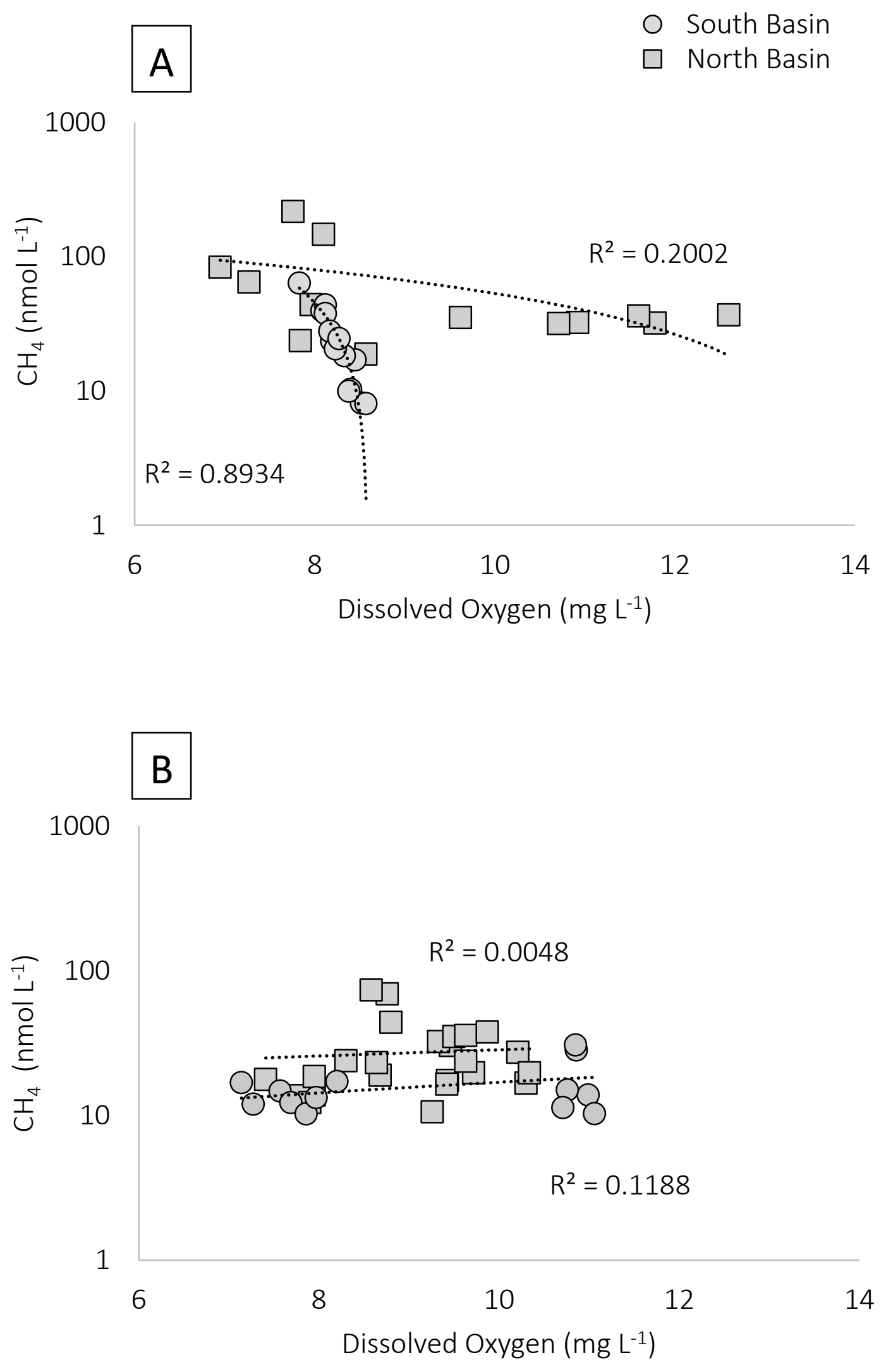


\title{
Electronic Supplementary Material
}

First estimation of the diffusive methane flux and concentrations from Lake Winnipeg, a large, shallow and eutrophic lake

\author{
Rachel R. Mandryk ${ }^{\mathrm{a}^{*}}$, David W. Capelle ${ }^{\mathrm{a}, 1}$, Cara C. M. Manning ${ }^{\mathrm{b}, 2}$, Philippe Tortell ${ }^{\mathrm{b}, \mathrm{c}}$, \\ Ross D. McCulloch ${ }^{\mathrm{b}}$, and Tim Papakyriakou ${ }^{\mathrm{a}}$
}

${ }^{\text {a }}$ Centre for Earth Observation Science, University of Manitoba, Winnipeg, MB, Canada

${ }^{\mathrm{b}}$ Department of Earth, Ocean and Atmospheric Sciences, University of British Columbia, Vancouver, BC, Canada

${ }^{c}$ Department of Botany, University of British Columbia, Vancouver, BC, Canada

*Corresponding Author: rachelmandryk@gmail.com 
Table S1: Summary statistics for Lake Winnipeg $\mathrm{CH}_{4}$ concentrations in $\mathrm{nmol} \mathrm{L}^{-1}$. Samples taken at one meter below surface depth are indicated as "surface" and samples taken from one meter above the lake bottom are marked as "bottom." All stations W01 - 65 are considered "north basin" and all stations W09 - 57B are "south basin" stations.

\begin{tabular}{|c|c|c|c|c|c|c|}
\hline Station & Summer 2018 & Fall 2018 & Winter 2019 & Spring 2019 & Summer 2019 & Fall 2019 \\
\hline W01 - Surface & 31.7 & 35.1 & & 27.2 & 13.2 & 59.3 \\
\hline W02 -Surface & 24.4 & 16.7 & & 9.5 & 25.7 & 27.1 \\
\hline W03 - Surface & 32.2 & 30.4 & 21.3 & 26.2 & 5.0 & 38.0 \\
\hline W04 - Surface & 33.1 & 23.7 & & 26.4 & 27.3 & 43.8 \\
\hline W05 - Surface & 36.9 & 23.8 & 24.7 & 21.9 & 69.2 & 15.1 \\
\hline W06 - Surface & 32.0 & 18.9 & 19.7 & 21.2 & 25.6 & 52.0 \\
\hline W07 - Surface & & 13.8 & 44.0 & 30.4 & 22.4 & 87.3 \\
\hline W08 -Surface & 20.6 & 17.1 & 10.2 & 19.2 & 26.0 & 43.5 \\
\hline W13 -Surface & 17.0 & 10.2 & 50.4 & 19.7 & 13.6 & 14.3 \\
\hline W14 - Surface & 18.8 & 69.1 & & 16.5 & 26.1 & 21.6 \\
\hline W01 - Bottom & 146.3 & 35.6 & & 31.9 & 41.4 & 70.3 \\
\hline W02 - Bottom & 36.2 & 16.5 & & 28.6 & 34.3 & 13.3 \\
\hline W03 - Bottom & 83.2 & 32.4 & & 25.4 & 61.3 & 54.4 \\
\hline W04 - Bottom & 33.7 & 23.2 & & 23.8 & 54.7 & 70.2 \\
\hline W05 - Bottom & 44.0 & 12.3 & & 35.8 & 12.2 & 13.2 \\
\hline W06 - Bottom & 64.7 & 18.5 & & 31.7 & 19.5 & 59.9 \\
\hline W07 - Bottom & 217.2 & 13.7 & & 21.6 & 126.7 & 285.3 \\
\hline W08 - Bottom & 24.6 & 17.8 & & 20.5 & 34.8 & 24.1 \\
\hline W13 - Bottom & 18.3 & 13.3 & & 19.4 & 22.8 & 15.3 \\
\hline W14 - Bottom & 23.7 & 73.7 & & 14.2 & 28.6 & 24.3 \\
\hline 2-M Inflow & 37.0 & & & 17.4 & 21.1 & 28.4 \\
\hline 2-M Outflow & 24.7 & & & 20.0 & 19.8 & 24.5 \\
\hline Warrens L. & 41.5 & & & 17.4 & 14.7 & 12.1 \\
\hline 9NS & & & & 48.8 & & \\
\hline $12 N S$ & & & & 26.1 & & 115.4 \\
\hline 19 & 35.1 & 19.7 & & 29.1 & 12.6 & 70.3 \\
\hline $23 S$ & & 27.3 & & 29.5 & 26.0 & 35.2 \\
\hline 34 & 28.3 & 17.5 & & 25.3 & 11.3 & 43.2 \\
\hline 39 & 63.2 & 43.9 & & 22.3 & 20.8 & 44.9 \\
\hline $41 S$ & 14.8 & & & 32.6 & 20.2 & 16.5 \\
\hline 45 & & 19.6 & & 17.9 & 43.2 & \\
\hline 54 & 18.7 & & & 13.7 & & 43.4 \\
\hline 64 & & 37.7 & & & & 160.9 \\
\hline 65 & 8.4 & & & 20.7 & 13.9 & \\
\hline W09 - Surface & 10.3 & 12.3 & 5.7 & 19.3 & 14.7 & \\
\hline W09 - Bottom & 9.9 & 11.9 & & 15.4 & 16.6 & 11.5 \\
\hline W10 - Surface & 8.1 & 10.3 & 6.5 & 17.0 & 21.0 & 55.1 \\
\hline W10 - Bottom & 8.1 & 11.3 & & 16.9 & 21.3 & 13.0 \\
\hline
\end{tabular}




\begin{tabular}{|c|c|c|c|c|c|c|}
\hline W11 - Surface & 43.8 & 13.8 & & 18.4 & 18.6 & 26.6 \\
\hline W11 - Bottom & 27.8 & 15.0 & & 15.9 & & 26.4 \\
\hline W12 - Surface & 39.5 & 28.3 & 64.0 & 22.0 & 48.7 & 41.1 \\
\hline W12 - Bottom & 37.6 & 30.7 & & 22.4 & 46.9 & 50.3 \\
\hline 1 & 462.6 & & & 282.5 & & \\
\hline 2 & 63.5 & & & 50.9 & 89.7 & 59.6 \\
\hline 4NS & & & & 29.0 & & 203.5 \\
\hline 7 & 733.8 & & & 153.5 & 142.8 & \\
\hline 7NS & & & & 31.0 & & 198.8 \\
\hline $12 B$ & & & & 18.3 & 18.0 & 24.4 \\
\hline $46 S$ & 23.6 & 16.9 & & 15.9 & 21.4 & 25.1 \\
\hline 57B & & & & & 18.3 & 54.4 \\
\hline Average & 67.0 & 23.8 & 27.4 & 31.7 & 32.7 & 54.9 \\
\hline Median & 32.1 & 18.5 & 21.3 & 22.0 & 21.9 & 42.1 \\
\hline Standard Deviation & 131.0 & 14.5 & 19.6 & 41.8 & 28.4 & 56.0 \\
\hline Minimum & 8.1 & 10.3 & 5.7 & 9.5 & 5.0 & 11.5 \\
\hline Maximum & 733.8 & 73.7 & 64.0 & 282.5 & 142.8 & 285.3 \\
\hline $\mathrm{N}$ & 40 & 35 & 9 & 48 & 42 & 44 \\
\hline
\end{tabular}




\section{Legend}

Methane Flux ( $\mu \mathrm{mol} \mathrm{m}^{-2} \mathrm{~h}^{-1}$ )

$0-0.10$

?

$0.1-1.0$

$1.0-10.0$

$10.0-100.0$

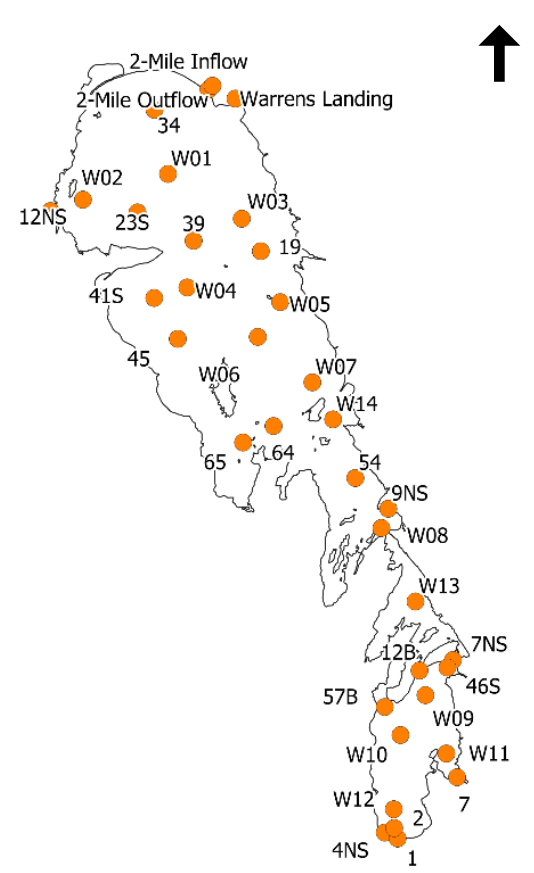

$\uparrow$
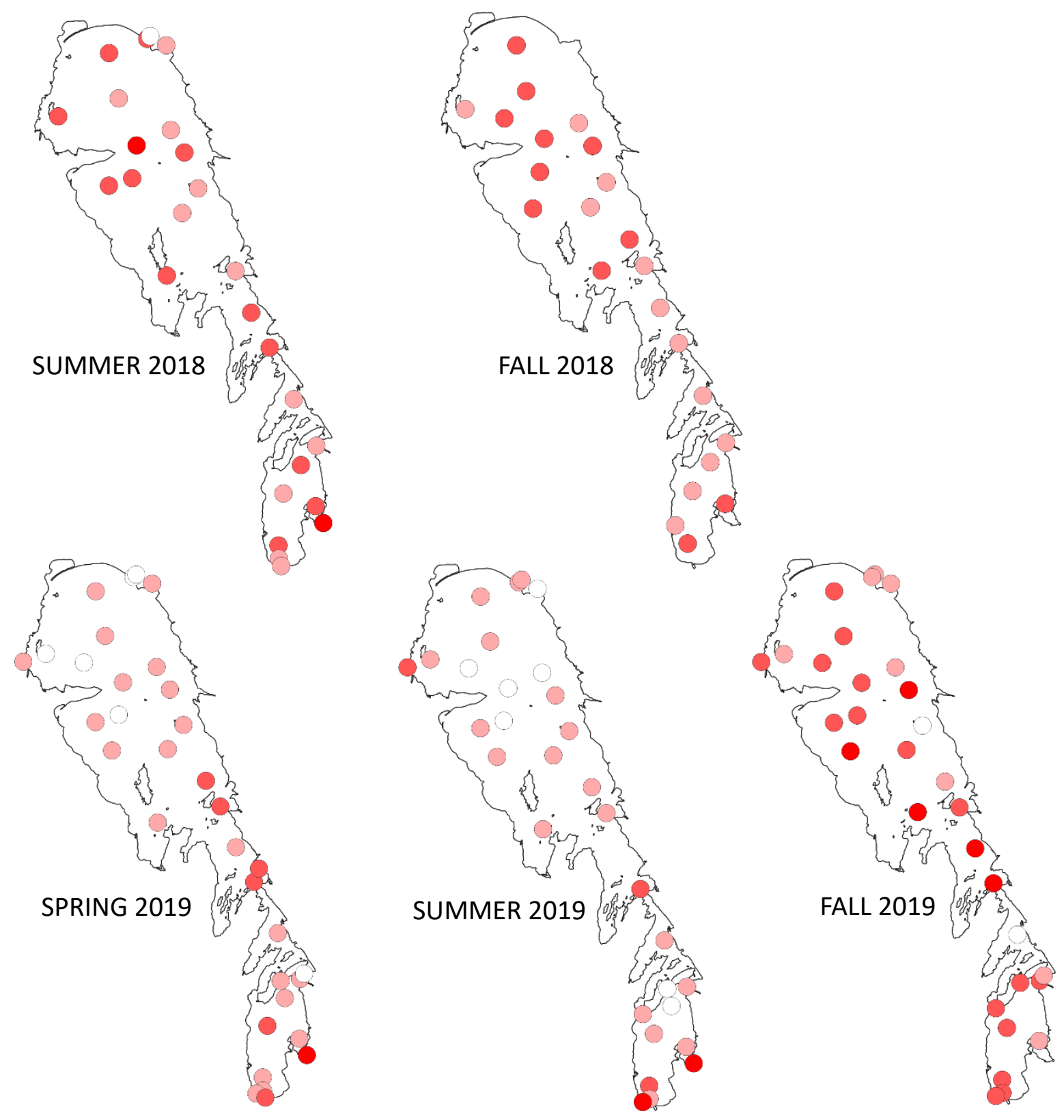

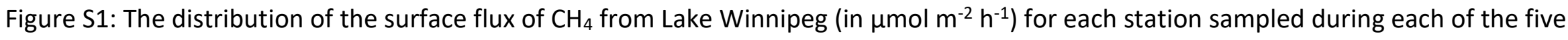
cruises. The sampling stations for Lake Winnipeg are provided on a separate map in lower left of the figure. The maps were generated using QGIS (2020). 